Hans Petter Graver. Rettslige sider ved forvaltningens mediehåndtering I: Tidsskrift for rettsvitenskap, 2007, no. 3, s. 321-60.

Artikkelen er utgitt på Universitetsforlaget (informasjon om tidsskriftet)

Lenke til artikkelen (tilgang til tidsskriftets originalversjon kan kreve abonnement).

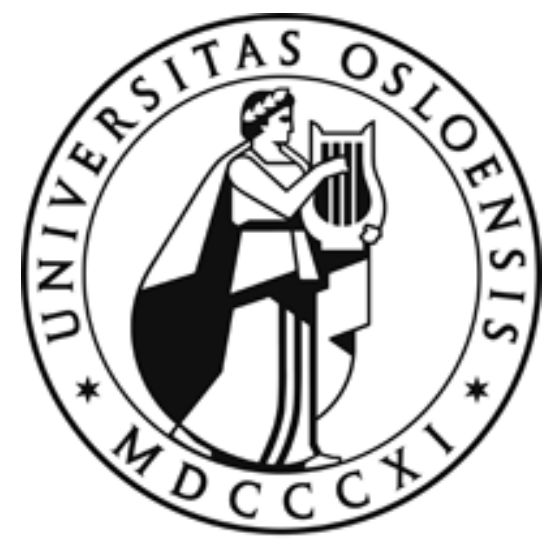




\section{RETTSLIGE SIDER VED FORVALTNINGENS MEDIEHÅNDTERING}

AV PROFESSOR HANS PETTER GRAVER

Forvaltningen har plikt til å drive aktiv informasjonsvirksomhet i medhold av Grunnloven $\$ 100$ sjette ledd som pålegger staten «at lægge Forholdene til Rette for en aaben og oplyst offentlig Samtale». I tillegg til å gi informasjon om regler og saker og skape forståelse for sin virksomhet, retter offentlige ledere en del av sin medieopptreden som påvirkningsforsøk mot regjeringen og Stortinget. Forvaltningen utvikler seg fra embetsverk til ideologiske statsapparater. Finnes noe demokratisk innsyn eller styring med meningsdannelsen innad i offentlige organer? Medieopptreden knytter seg ofte til saker som forvaltningen enten behandler, aktivt kommuniserer eller kommenterer på bakgrunn av offentlig omtale. Man kan spørre om forvaltningen må gjøre noe for å sikre interessene for den som blir gjenstand for omtale, hvilken plikt forvaltningen har til å søke at alle sider ved saken kommer frem og når forvaltningen kan stilles til ansvar for skadevirkninger av informasjonen. Et sentralt tema er om svarene i det hele tatt kan gis på rettsregelplan, eller om det er snakk om mer uforpliktende krav til god forvaltningsskikk, dvs at den primære reaksjonen på en uriktig eller ubehagelig omtale bør være å gripe til den offentlige meningsveksling, ikke til rettslige angrep på omtalen.
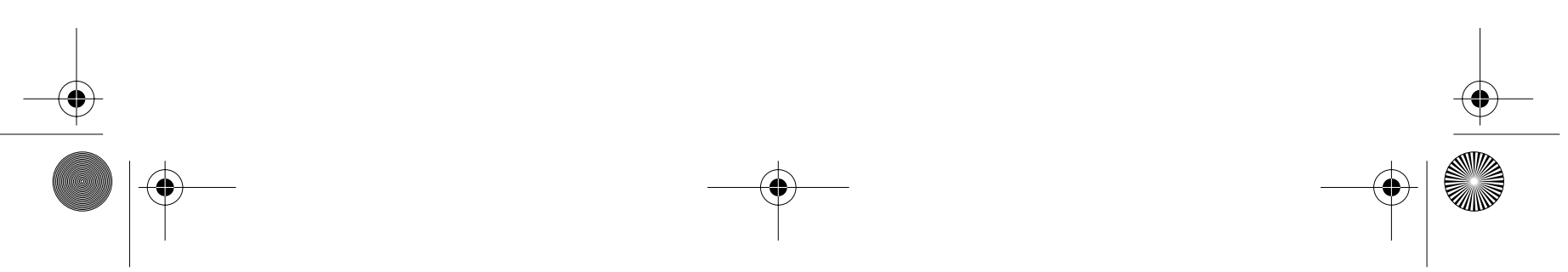


\section{Problemstilling og avgrensning}

Forvaltningen og forvaltningens virksomhet har stor oppmerksomhet $\mathrm{i}$ det moderne mediebildet. Informasjon brukes aktivt som virkemiddel både av forvaltningen og forvaltningens parter, og uavhengige media er en stadig mer sentral kanal for dette. Forvaltningen tilrettelegger sin informasjon for å nå ut som nyheter i kampen om de gode oppslag. Offentlige organer må dessuten ofte forholde seg til nyhetsoppslag som har sin bakgrunn i opplysninger fra offentlige virksomhet som er tilgjengelig gjennom offentlighetsloven, lekkasjer eller fra parter som bruker media aktivt som ledd i sin strategi.

Den svenske statsviteren Bo Rothstein snakker om en utvikling av forvaltningen fra embetsverk til ideologiske statsapparater. ${ }^{1}$ Trekk ved denne utviklingen er bl.a. at det opprettes stadig flere offentlige organer som i hovedsak har ideologiske oppgaver. Også i norsk forvaltning er enkelte institusjoner og stillinger opprettet for å sikre en institusjonell kritikk, overvåkning eller opposisjon. Typiske eksempler på dette er forbrukerombudet, barneombudet og Likestillings- og diskrimineringsombudet som allerede ved opprettelsen er tiltenkt spesielle informasjonsoppgaver innen sine områder. Ombudene benytter seg ofte av media til å påkalle offentlighetens oppmerksomhet om en sak eller et problemområde. Det kan hevdes at retten til kritisk og offentlig opposisjon en grunnforutsetning for opprettelse og opprettholdelse av mange ombudsordninger. ${ }^{2}$ Aktiv medieopptreden er likevel ikke noe som er forbeholdt ombud, men er en sentral del av virksomheten til mange forvaltningsorganer både i sentralforvaltningen og ytre etater.

Internasjonalt snakker man om fremveksten av "spin doctors» som en ny yrkesgruppe også i forvaltningen som har som oppgave å sørge for at mediene og offentligheten fortolker begivenheter fra en særlig synsvinkel. Betegnelsen oppsto i USA i midten av 1980-tallet og ble via Storbritannia utbredt til Europa på slutten av 1990-tallet. Betegnelsen brukes på personer som er ansatt tett opp til ledelsen i en organisasjon og som har en særlig kommunikasjonskompetanse. Gjennom intensiv pleie av mediekontakter søker de å gi en historie den rette «spin», dvs.

1 Bo Rothstein, Från ämbetsverk till ideologiska statsapparater i Bo Rothstein og Lotta Vahlne Westerhäll (red.) Bortom den starka statens politik? Stockholm 2005 s. 186-220.

2 NOU 1999:27 «Ytringsfrihed bør finde Sted» s. 131.
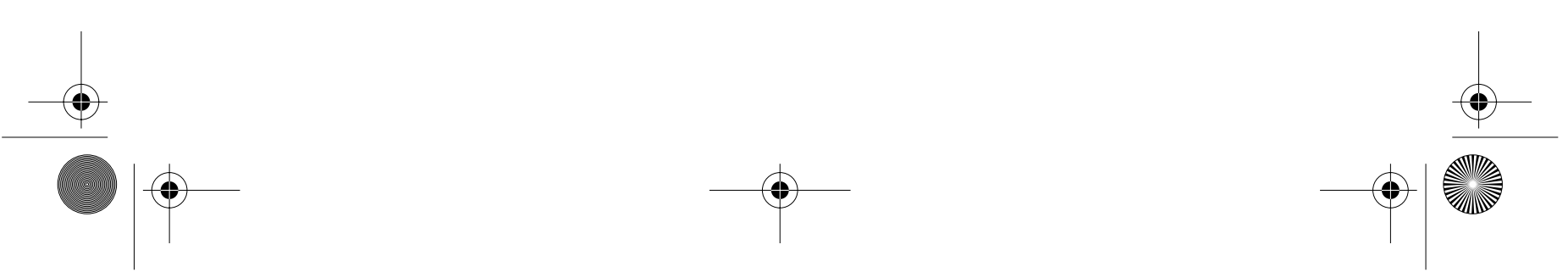
den riktige dreining i forhold til ledelsens interesser. Spindoktorene er også hyppig nære rådgivere for de politiske beslutningstakerne slik at strategisk og politisk-taktisk rådgivning inngår i deres oppgaver. ${ }^{3}$ Mens det bl.a. i Danmark har vært stor debatt om slik bruk av media fra forvaltningens side, har det i Norge ikke ledet til offentlige kontroverser, uten at dette har noen nødvendig sammenheng med forskjeller i mediestrategien til forvaltningen i Danmark og Norge. En forskjell er det imidlertid $\mathrm{i}$ at informasjonsmedarbeiderne i norsk forvaltning ikke i like stor grad er politisk ansatte.

Et annet trekk i utviklingen av forvaltningens medieopptreden er at den ideologiske debatt i samfunnet iblant utspiller seg mellom ledere for offentlige virksomheter. I Norge er dette til og med institusjonalisert for eksempel gjennom konkurranseloven $₫ 9$ (e) om at Konkurransetilsynet skal påpeke konkurranseregulerende virkninger av offentlige tiltak. Offentlige ledere retter ofte en del av sin medieopptreden som påvirkningsforsøk mot regjeringen og Stortinget, for eksempel gjennom debattartikler og kampanjer. I enkelte tilfeller er dette uttrykkelig del av etatens mandat slik som for eksempel i bakgrunnen for opprettelsen av Mattilsynet, hvor det i forarbeidene til matloven uttales at «Mattilsynet skal spille en selvstendig rolle og i kraft av sin tyngde og kompetanse framstå som en premissleverandør for, og i gitte situasjoner også som faglig korrektiv til det politiske miljø.» ${ }^{4}$ Men også i andre tilfeller går offentlige organer aktivt ut i media for eksempel med sine høringsuttalelser til nye lover eller forskrifter for å skape offentlighet om dem.

Sentrale spørsmål som kan stilles er om det finnes noe demokratisk innsyn eller styring med meningsdannelsen innad i offentlige organer, og om offentlige organer er i ferd med å overta partienes rolle som arena å søke seg inn i for folk med politiske ambisjoner innen et samfunnsfelt. ${ }^{5}$ Medieopptreden knytter seg ofte til saker som forvaltningen enten behandler, aktivt kommuniserer eller kommenterer på bakgrunn av offentlig omtale. Man kan i slike tilfelle spørre når forvaltningen har plikt til å kommunisere og når den har plikt til å la være. Når den først kommuniserer melder spørsmålet seg om hva forvaltningen må gjøre for å

\footnotetext{
3 Se Betænkning nr. 14432004 fra det danske Finansministeriet - Embedsmænds rådgivning og bistand s. 90-91.

4 St. prp. nr. 1 tillegg nr. 8 (2002-2003).

5 Se Rothstein, op. cit. s. 211 og 216.
}
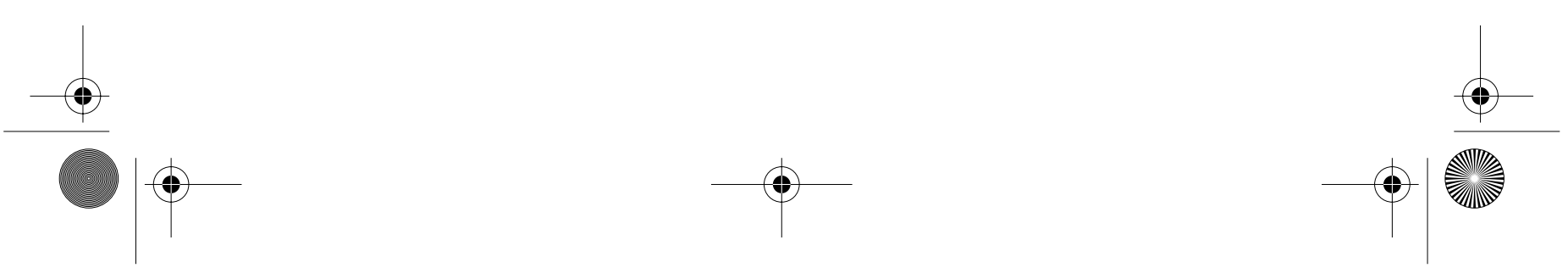
sikre interessene for den som er gjenstand for omtale, og hvilken plikt forvaltningen har til å søke at alle sider ved saken kommer frem. Blir noen gjenstand for uriktig eller ensidig omtale fra forvaltningens side, kan det spørres om forvaltningen kan stilles til ansvar. Man kan også stille spørsmål ved hvilken frihet et forvaltningsorgan har til å fremme bestemte synspunkter uavhengig og kanskje på tvers av synet til regjeringen og andre overordnede organer.

Forvaltningens mediestrategi bør ses i en større sammenheng. Reglene og praksis rundt informasjon fra forvaltningsorganer kan utnyttes av andre som ledd i deres informasjons- og mediestrategi. Et klassisk eksempel fra Sverige har vi hvor noen aktivister sendte inn Scientologibibelen til et offentlig organ, for på denne måten å få den kopiert og distribuert uten samtykke fra rettighetshaveren ved at folk begjærte innsyn etter offentlighetsreglene. ${ }^{6}$ Praksis fra Konkurransetilsynet tyder på at klage til tilsynet utnyttes strategisk av markedsaktører overfor konkurrenter. Gjennom offentlighet om tilsynets saker kan det være en måte å ramme konkurrenten på, uavhengig av sakens endelige utfall. ${ }^{7}$

Forvaltningens mediehåndtering har berøringsflater til spørsmålet om embets- og tjenestemenns ytringsfrihet og deres lojalitet. Det er jo disse som uttaler seg eller skriver i mediene på organets vegne. Det som er temaet her er hva som gjelder når ansatte uttaler seg på vegne av sin etat eller i embets medfør. Spørsmålet blir deres ytringsfrihet i denne sammenheng, herunder hvordan den begrenses av deres plikt til lojalitet i embetsførselen. Spørsmålet om hvilken adgang ansatte i forvaltningen har til å ytre seg og delta i den offentlige meningsdannelse på egne vegne, faller utenfor behandlingen. Det er grunn til å minne om at når det er snakk om topplederes ytringer innen eget fagfelt er det vanskelig å trekke noen slik grense.

Det gjelder også rettslige føringer for hvordan forvaltningen skal behandle journalister og andre representanter for mediene, og hvilke rettigheter disse har i forhold til forvaltningens informasjonsvirksomhet. Offentleglovas regler er her selvsagt sentrale. I tillegg kommer spørsmål om adgangen for forvaltningen til å forskjellsbehandle gjennom å gi visse media eksklusivitet eller fortrinn til informasjon. Dette spørsmålet

6 Se Prop. 1999/2000:35.

7 Se Øystein Foros og Erling Hjelmeng, Virker konkurranseloven prisdrivende?

Økonomisk forum Nr. 12006 s. 1-9.
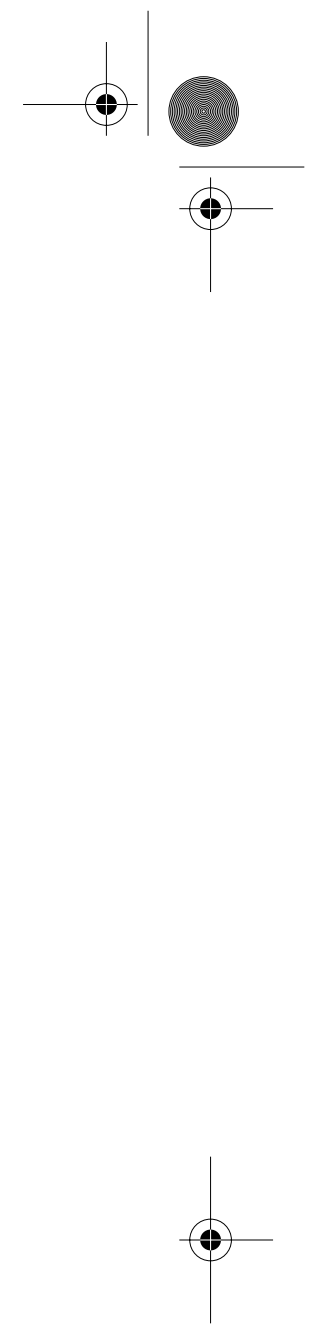
må løses med utgangspunkt i det alminnelige krav til saklighet og likebehandling, slik at forskjellsbehandling i form av eksklusivitet bare kan skje hvor det er et saklig grunnlag for det. $^{8}$ Det kan være saklig å samarbeide med et eller et fătall medier om en lansering, men det er ikke saklig generelt å forbeholde "godbiter» til medier som er vennlig stemt overfor forvaltningen. Anvendelse av likhetsgrunnsetningen kan dessuten gi forskjellig resultat avhengig av om det er snakk om forvaltningens aktive informasjonsformidling eller den passive, dvs. behandling av begjæringer om innsyn etter offentleglova. Et tredje spørsmål er når det kan settes sperrefrist ved utlevering av informasjon Jeg går ikke nærmere inn på disse spørsmålene her.

Det er bare få av de spørsmål som er reist her som har sikre rettslige svar. Utgangspunktene er klare: Forvaltningen har et informasjonsansvar, saksdokumentene er offentlige og visse opplysninger er taushetsbelagt. Når det gjelder de øvrige spørsmål som kan stilles om krav til innhold, form og prosedyre for forvaltningens mediehåndtering er et sentralt spørsmål om svarene i det hele tatt kan gis på rettsregelplan, eller om det er snakk om mer uforpliktende krav til god forvaltningsskikk. I det følgende skal jeg søke svar på dette. Først vil jeg si noe om bakgrunn og rammer for forvaltningens mediehåndtering. Deretter presenterer jeg de generelle rettslige føringer, informasjonsplikt, offentlighet og taushetsplikt. Så gjennomgår jeg de krav som eventuelt kan stilles til saksbehandlingen når forvaltningen gir informasjon om enkeltsaker eller om andre forhold som kan få konkrete virkninger for private. En kort diskusjon av forvaltningsorganers opptreden i en offentlig diskusjon med øvrige deler av det politiske og administrative systemet følger, før jeg endelig trekker en kort konklusjon om karakteren og innholdet av reglene for forvaltningens mediehåndtering.

\section{Bakgrunn og rammer for forvaltningens mediehändtering}

Styring og ledelse på de fleste samfunnsområder forutsetter evne til offentlig kommunikasjon. Informasjonsstrategier brukes aktivt av bedrifter og organisasjoner for å påvirke almenhet og myndigheter i saker som

\footnotetext{
8 Se nærmere redegjørelsen til Jens Peter Christensen, Embedsmænds rådgivning og
bistand i Henriksen, Rønsholdt og Blume (red.), Forvaltningsretlige perspektiver, Kø-

8 Se nærmere redegjørelsen til Jens Peter Christensen, Embedsmænds rådgivning og
bistand i Henriksen, Rønsholdt og Blume (red.), Forvaltningsretlige perspektiver, København 2006 s. 309-345 på s. 339-343.
}
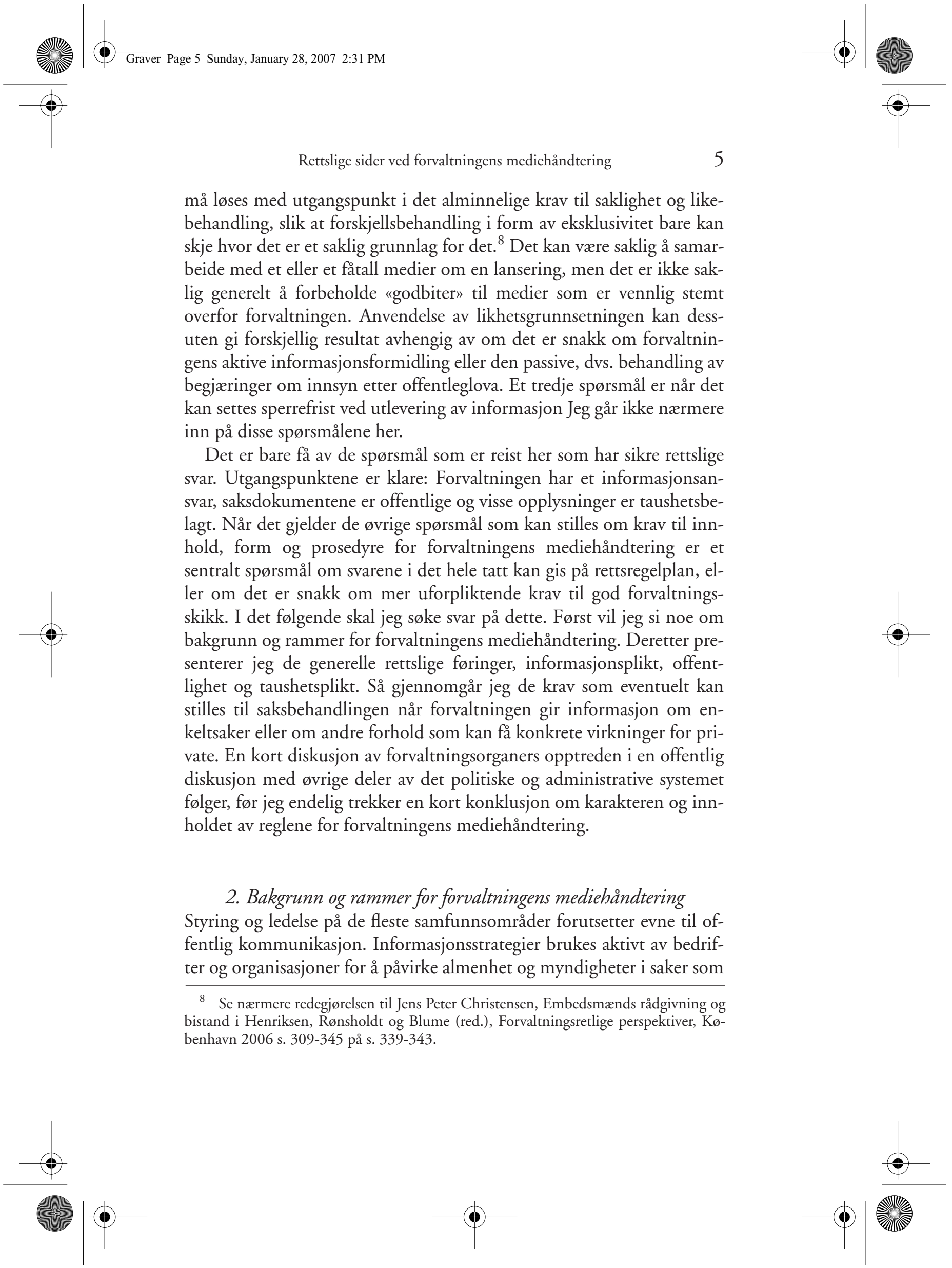
er viktige for dem. Maktutredningen skriver at «massemediene er blitt den sentrale arenaen for kampen om politisk makt. De er også blitt viktigere i kampen om økonomisk makt. Mediene er blitt mer politisk uavhengige, de er ikke lenger talerør for partier og politiske institusjoner. De er derimot viktigere i kroning og detronisering av politiske og andre ledere. En redigert offentlighet krever at politikere og andre aktører tilpasser seg en journalistisk form og utnytter medienes særtrekk når de søker innflytelse.» ${ }^{9}$ Denne erkjennelsen preger også det offentliges informasjons- og kommunikasjonspolitikk. Det er i tråd med dette når for eksempel Kommunaldepartementet skriver om etatene i utlendingsforvaltningen at «UDI og UNE skal fortsatt satse på helhetlig og målrettet kommunikasjon mot brukere, samarbeidspartnere og samfunnet for øvrig. Synliggjøring av resultater i media og å sette i verk alle deler av det utvidede informasjonsprogrammet for asylsøkere er satsingsområder for UDI.» ${ }^{10}$

Forvaltningens mediestrategi har sammenheng med den økede grad av resultatorienteringen i forvaltningen. Etater og ledere i forvaltningen er blitt friere med hensyn til bruk av virkemidler. Til gjengjeld stiller budsjettdokumentene strengere krav til resultatene. Etter som offentlige organer og virksomheter får større selvstendighet og frihet til å velge hvordan de vil oppfylle de resultatforventninger som rettes til dem, åpnes det for at det kan utvikles lokale strategier som presiserer hvilke mål som skal etterstrebes, og hva slags kompetanse og andre ressurser som må være på plass for at målene skal nås. Den økede budsjettfriheten har gitt muligheter for prioritering og oppbygging av egne informasjonsstaber som tilrettelegger og gjennomfører organets informasjonspolitikk og mediehåndtering. Strategiarbeid er en brekkstang for ledere til å agere mer offensivt på vegne av sine virksomheter, enn det budsjettprosesser i offentlig forvaltning tradisjonelt har gitt rom for. ${ }^{11}$

Plikten til å oppnå resultater stiller større krav til forvaltningen om å velge de beste virkemidler som står til disposisjon. Informasjon er i denne forbindelse et virkemiddel, og måten pressen brukes på for å nå ut med informasjon en viktig del av forvaltningens resultatoppnåelse. Illu-

\footnotetext{
9 NOU 2003:19 Makt og demokrati s. 48.

10 St. prp. nr. 1 (2005-2006) fra Kommunal- og regionaldepartementet s. 92.

11 Tom Colbjørnsen, Modernisering og fornyelse i staten Erfaringer, dilemmaer og utfordringer for toppledere, Rapport til moderniseringsdepartementet 2004.
}
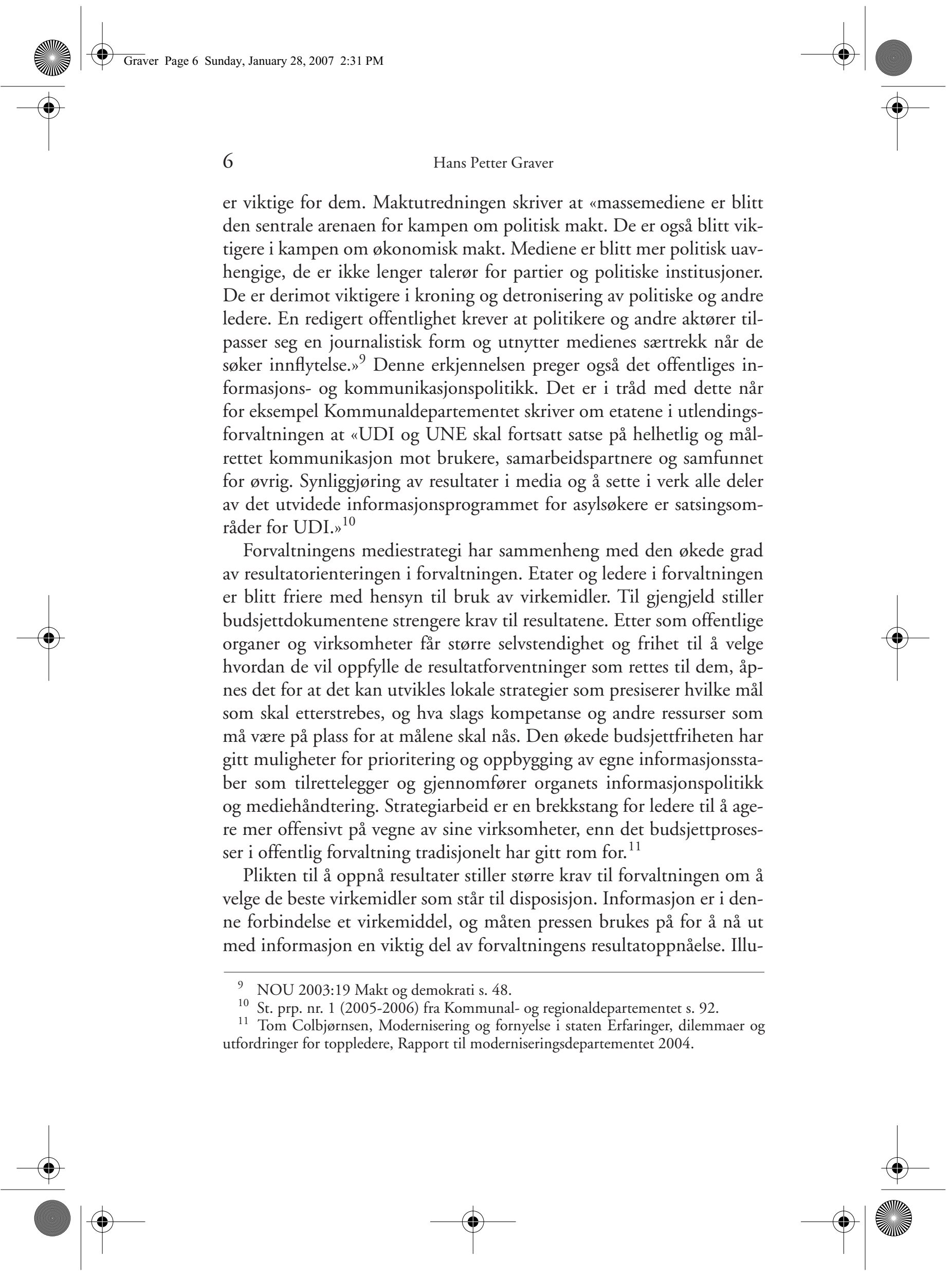
strerende er proposisjonen om opprettelsen av Mattilsynet der det er lagt stor vekt på offentlig kommunikasjon som del av tilsynets oppgaver. Tilsynet skal «bidra til at brukerne blir gode til å løse sine utfordringer» gjennom aktiv veiledning om innholdet i regelverket, videreformidling av sin kunnskap om risikofaktorer i matproduksjonen og annet forebyggende arbeid og skal sørge for en aktiv kommunikasjon, herunder risikokommunikasjon og informasjon til allmennheten om tilsynets vurderinger og resultater. ${ }^{12}$

Som maktutredningen skriver har den politiske selvstendiggjøringen av mediene bidratt til profesjonalisering av medienes kilder innen politikk, forvaltning, organisasjonsliv og næringsliv. Informasjonsbransjen var en av 1990-årenes store vekstbransjer, også innenfor offentlig forvaltning. ${ }^{13}$ Samtidig fører medienes økende interesse for enkeltsaker til at forvaltningen oftere kommer i offentlighetens søkelys. Dette forsterkes av større offentlighet rundt forvaltningens saksbehandling. Det skjer også en politisering av saksbehandlingen som gjør statlige ledere mer synlige og ansvarliggjorte på den offentlige arena. Eksempelvis kan nyanser i en høringsuttalelse bli slått stort opp i mediene, med det resultat at statsråden på det aktuelle området engasjerer seg. Dermed kan ledere komme i klemme mellom sine saksbehandleres faglige vurderinger på den ene siden, og politikere og medier på den annen side.

Rammene for statsforvaltningens mediehåndtering er lagt i statens informasjonspolitikk. ${ }^{14}$ Målene for informasjonspolitikken er at befolkning, næringsliv og organisasjoner skal ha lik og alminnelig tilgang til å delta aktivt i den demokratiske prosessen, fa informasjon om sine rettigheter, plikter og muligheter og ha reell tilgang til informasjon om det offentliges aktiviteter. Ytringsfrihetskommisjonen understreket betydningen av en rimelig åpen informasjonstilgang fra forvaltningens side som «en forutsetning for at man på en meningsfull måte skal kunne holde seg underrettet fra tilgjengelige kilder». ${ }^{15}$ Informasjonspolitikken skal dessuten bidra til bruk av informasjon og kommunikasjon som vir-

\footnotetext{
12 St. prp. nr. 1 tillegg nr. 8 (2002-2003) Landbruksdepartementet.

13 Til illustrasjon kan nevnes at alle fylkesmannsembetene opprettet informasjonsrådgiverstillinger i løpet av 1990-tallet, se Hans Chr. Høyer, Evaluering av informasjonsstillingene i fylkesmannsetaten, Høgskolen i Hedmark Rapport nr. 21 - 1999.

${ }_{14}$ Informasjonspolitikk for statsforvaltningen, Arbeids- og administrasjonsdepartementet 2001 s. 6.

${ }^{15}$ NOU 1999:27 «Ytringsfrihed bør finde Sted» s. 89.
}
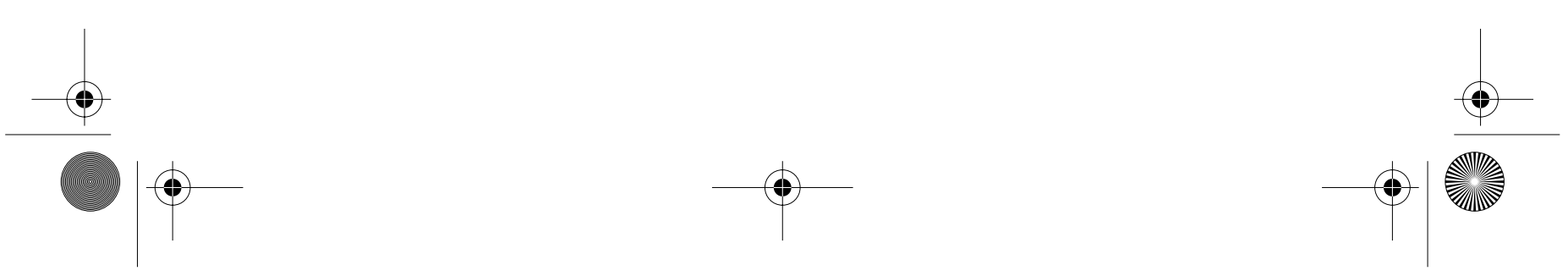
kemiddel for å nå politiske mål. Utvalget som vurderte grunnlaget for statens informasjonspolitikk fremhevet i tillegg forvaltningens egenprofilering som et mål, fordi profilering kan være av stor betydning for å gjøre organets virksomhet kjent, og dermed dens tjenester, og for å styrke den interne kulturen og selvfølelsen. ${ }^{16}$ Dette er også sentralt ledd i mange organers kommunikasjonsstrategi. I kommunikasjonsstrategien til Post- og teletilsynet heter det for eksempel «ekstern kommunikasjon skal kjennetegnes av en uredd holdning og være etterrettelig. Informasjon fra PT skal gi mottakerne et godt grunnlag for å forstå hva PT gjør og hvorfor, samt hvilke konsekvenser PTs virksomhet har for brukerne.»

Utvalget skilte mellom fire typer informasjonsvirksomhet og kommunikasjon: Plikt- og rettighetskommunikasjon, kommunikasjon om offentlig administrasjon og virksomhet, holdningskapende informasjon og kommunikasjon knyttet til omfattende kriser og katastrofer. ${ }^{17}$ Plikt og rettighetskommunikasjon er en forutsetning for å kunne sette i verk lover og regler, og er også vesentlig for at folk skal kunne innrette seg etter plikter og oppnå rettigheter. Slik kommunikasjon skjer selvsagt gjennom tradisjonell opplysningsvirksomhet, men også gjennom mer aktiv bruk av media. For eksempel skriver Datatilsynet i sin årsmelding for 2004 at «for å skape merksemd og interesse kring personvernspørsmål deltek Datatilsynet aktivt i den offentlege debatten og legg stor vekt på å praktisere meirinnsyn.» ${ }^{18}$ Kommunikasjon om offentlig administrasjon og virksomhet skal veilede den enkelte i sitt forhold til forvaltningen slik at de vet hvor de skal henvende seg og hvordan de kan påvirke beslutningsprosessen. Holdningskapende kommunikasjon har som oftest som mål å sikre felles gode eller unngå felles «onder» ved å få folk til å vise forsiktighet, avstå fra visse typer handlinger eller fremme verdier. Krise- og katastrofeinformasjon inngår som del av beredskapsvirksomheten, men omfatter også informasjon om konkrete farer i mindre sammenhenger for eksempel Mattilsynets informasjon om risikoen for e.coli smitte fra konkrete matprodukter.

Selv om man analytisk kan skille mellom disse typene informasjonsvirksomhet, glir de i praksis ofte over i hverandre. Informasjon om ret-

16 NOU1992:21 Ikke bare ord ... Statlig informasjon mot år 2000 s. 29.

17 NOU1992:21 Ikke bare ord ... Statlig informasjon mot år 2000 s. 29-32.

18 Datatilsynets årsmelding 2004, vedlegg til St.meld. nr. 40 (2004-2005).
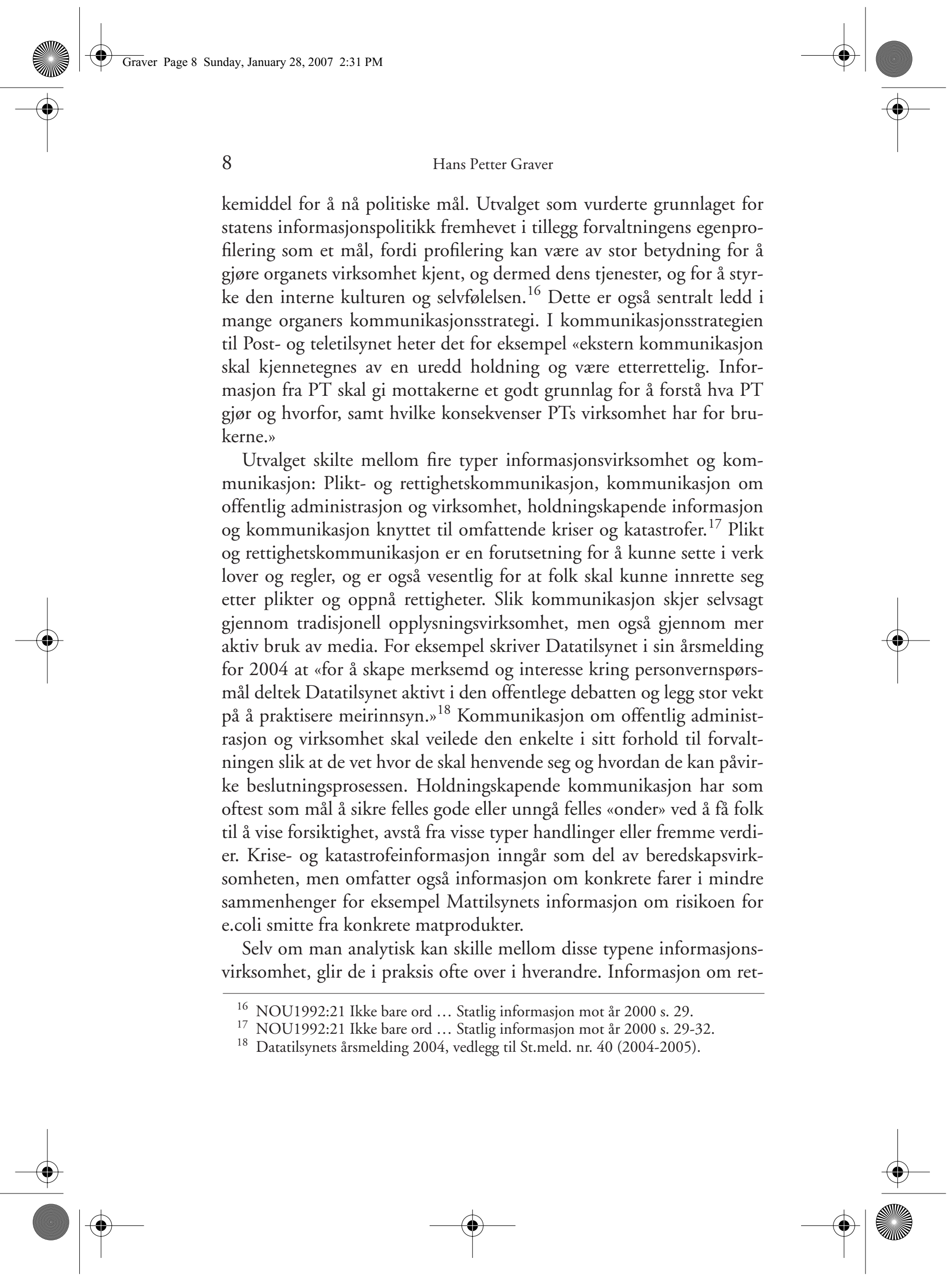
tigheter og plikter kan skje gjennom informasjon om enkeltsaker. Dette kan også være del i det holdningskapende arbeide. For eksempel forsøker Konkurransetilsynet ved hjelp av konkrete saker å vise hva konkurransereglene betyr i praksis, både gjennom egne kanaler og gjennom media. Samtidig bruker tilsynet informasjon om aktuelle saker som et virkemiddel for å synliggjøre sin virksomhet og rolle i samfunnet. ${ }^{19}$ Flere av sakene tilsynet har behandlet har fått stor oppmerksomhet.

\section{Generelle rettslige foringer på forvaltningens mediehåndtering}

\subsection{Innledning}

Forvaltningens mediehåndtering er i liten grad underlagt spesiell rettslig regulering. Den må imidlertid skje innenfor rammene av de regler som gjelder forvaltningens informasjonshåndtering og -formidling generelt. For informasjonshåndteringen har vi både regler som pålegger forvaltningen å frembringe og ha informasjon, å gi veiledning generelt og i enkeltsaker, å gi innsyn i informasjon og aktivt å gå ut med informasjon, samtidig som vi også har regler om vern av informasjon. Reglene kan gjelde rettigheter og plikter i forhold til bestemte personer som parter i en forvaltningssak og i forhold til en ubestemt krets og almenheten mer generelt. Sentrale regelsett er forvaltningsloven, offentlighetsloven, personopplysningsloven og miljøinformasjonsloven. I tillegg finnes det spesialregulering som for eksempel konkurranseloven $₫ 22$ om offentliggjøring av vedtak.

\subsection{Forvaltningens aktive informasjonsplikt}

Det finnes ingen generell lovbestemmelse som pålegger forvaltningen aktivt å informere offentligheten om sin virksomhet. Likevel må det antas at det eksisterer en slik plikt, og at denne omfatter både å gi informasjon generelt om det området et organ administrerer og $\mathrm{i}$ en viss utstrekning om enkeltsaker. En plikt for staten til av eget tiltak å gå ut med informasjon til allmennheten kan bygges på Grunnloven $\$ 100$ sjette ledd som pålegger staten «at lægge Forholdene til Rette for en aaben og

\footnotetext{
19 Se St.prp. nr. 1 (2005-2006) Moderniseringsdepartementet s. 90.
}
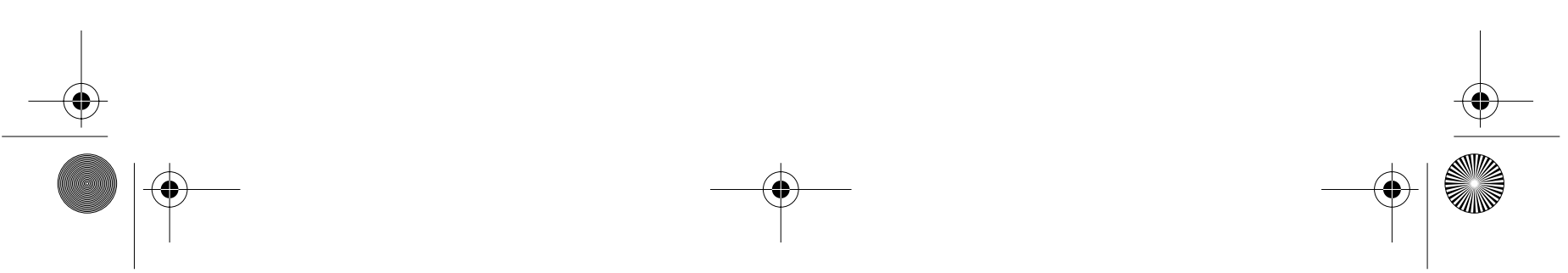
oplyst offentlig Samtale». Å legge til rette for en «opplyst» samtale, dvs. kvalitet og mangfold i den offentlige debatt vil innebære at staten i mange sammenhenger må være forpliktet til en aktiv informasjonsvirksomhet, både om egen og privates virksomhet. ${ }^{20}$ En slik plikt kan også støttes på EMK artikkel 10. Ombudsmannen legger for sin praksis til grunn at offentlige myndigheter har en generell plikt til aktivt å bidra til å gi informasjon på sitt forvaltningsområde. ${ }^{21}$

Et generelt uttrykk for en slik plikt finnes i statens informasjonspolitikk. ${ }^{22}$ I tillegg er ofte slike plikter konkretisert som ledd i etatsyringen. ${ }^{23}$ Forvaltningens veiledningsplikt i forvaltningsloven, og for en rekke organer også i spesiallovgivningen eller i organets mandat, har i praksis også betydning for forvaltningens mediehåndtering og aktive informasjonsvirksomhet. Den alminnelige veiledningsplikten gjelder bare i tilknytning til konkrete saker eller henvendelser. ${ }^{24}$ Det betyr at ingen på dette grunnlag har rettskrav på at forvaltningen gir generell informasjon. Forvaltningen kan imidlertid et stykke på vei oppfylle sin plikt til å veilede individuelt gjennom å gi generell informasjon, og ser ofte dette som en rasjonell måte å organisere sin veiledning på.

Aktiv informasjon er en naturlig del av offentlig tilsynsvirksomhet. For eksempel uttaler departementet om Kredittilsynet i forarbeidene til eiendomsmeglerloven:

«En viktig side av tilsynsarbeidet er å orientere markedet, det vil særlig si mulige klienter, også om kritikkverdige forhold. Tilsynsmyndighetene må kunne uttale kritikk mot navngitte firmaer og enkeltpersoner når de opptrer kritikkverdig selv om en ikke vurderer å anvende lovens sanksjonsmidler. Dette innebærer at tilsynsmyndighetene kan offentliggjøre faktiske opplysninger, sine egne vurderinger og eventuelle saksbehandlingsskritt, for eksempel oversendelse til andre offentlige myndigheter. Det inngår i tilsynsmyndighetenes arbeidsoppgaver å informere om slike forhold og tiltak, og en høy grad av offentlighet er en forutsetning for tilsynsarbeidets effektivitet.» ${ }^{25}$

${ }^{20}$ NOU 1999:27 «Ytringsfrihed bør finde Sted» s. 250.

21 Se for eksempel Sivilombudsmannens årsmelding 2002 s. 79.

${ }^{22}$ Se også etiske retningslinjer for statstjenesten pkt. 3.2.

23 Se til illustrasjon eksempelet fra Utlendingsdirektoratet referert ovenfor i note 10.

${ }^{24}$ Se for en oversikt Hans Petter Graver, Konkurransetilsynets veiledningsplikt - på bakgrunn av forvaltningens alminnelige veiledningsplikt i Tidsskrift for forretningsjus 2004 s. $187-205$.

25 Ot.prp.nr.59 (1988-1989) Om lov om eiendomsmegling s. 39.
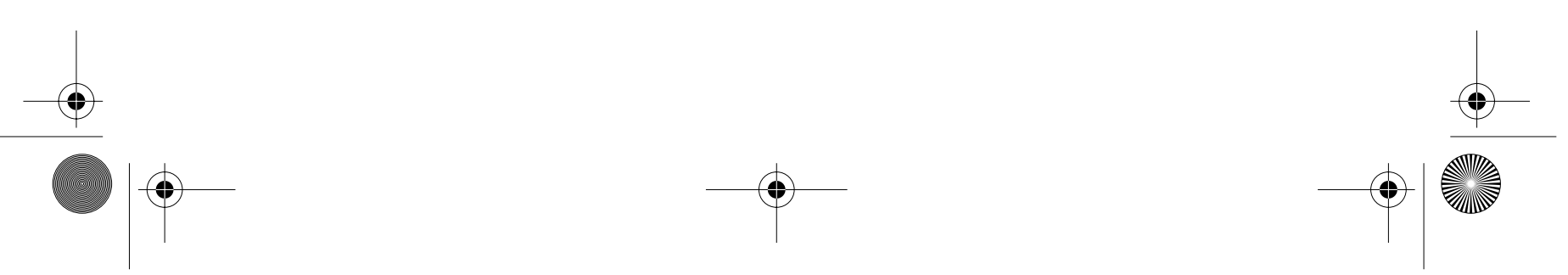
Tilsvarende heter det i forarbeidene til matloven at informasjon og veiledning om regelverkets innhold og fortolkning er en av Mattilsynets fire hovedoppgaver. ${ }^{26}$ For Mattilsynets vedkommende er informasjonsplikten lovfestet i matloven $\$ 27$, se nærmere avsnitt 3.4 nedenfor. For Konkurransetilsynet fremgår en informasjonsplikt av konkurranseloven $\$ 9$ bokstav c om at tilsynet skal iverksette tiltak for å øke markedenes gjennomsiktighet.

\subsection{Offentlighet}

Det regelsettet som i praksis har størst betydning for forholdet mellom forvaltningen og media er reglene om offentlighet i forvaltningen $\mathrm{i}$ offentleglova. Denne loven fastslår i $\$ 3$ hovedregelen om at dokumenter, journaler og lignende registre er åpne for innsyn dersom ikke annet følger av lov eller forskrift med hjemmel i lov. Formålet med loven er etter $\$ 1$ «å leggje til rette for at offentleg verksemd er open og gjennomsiktig, for slik å styrkje informasjons- og ytringsfridommen, den demokratiske deltakinga, rettstryggleiken for den enkelte, tilliten til det offentlege og kontrollen frå ålmenta». Begrunnelsen for loven er blitt utvidet som ledd i utviklingen av mediesamfunnet fra den gamle lovens hovedvekt på rettssikkerhet og kontroll, til den nye lovens understrekning av offentlighet i forvaltningen som en fundamental demokratisk rettighet. I proposisjonen heter det således:

«Innsynsretten kan på fleire måtar vere med på å styrkje demokratiet i samfunnet. Retten til innsyn i offentlege dokument er ein viktig del av den vidare informasjonsfridommen, og ein føresetnad for ein informert samfunnsdebatt. Ei open forvaltning vil medverke til å styrkje borgarane si innsikt i samfunnsspørsmål, og dermed til auka interesse for og deltaking i politiske debattar og prosessar. Retten til informasjon er ein føresetnad for å realisere den demokratiske retten til deltaking også mellom valperiodane. Prinsippet om at borgarane har rett til innsyn i saksdokumenta $\mathrm{i}$ forvaltninga er såleis eit fundamentalt prinsipp $\mathrm{i}$ vårt representative demokrati.» ${ }^{27}$

\footnotetext{
${ }^{26}$ Ot.prp.nr.100 (2002-2003) Om lov om matproduksjon og mattrygghet mv. (matloven) s. 23-24.

27 Ot.prp.nr.102 (2004-2005). Om lov om rett til innsyn i dokument i offentleg verksemd (offentleglova) s. 24-25.
}
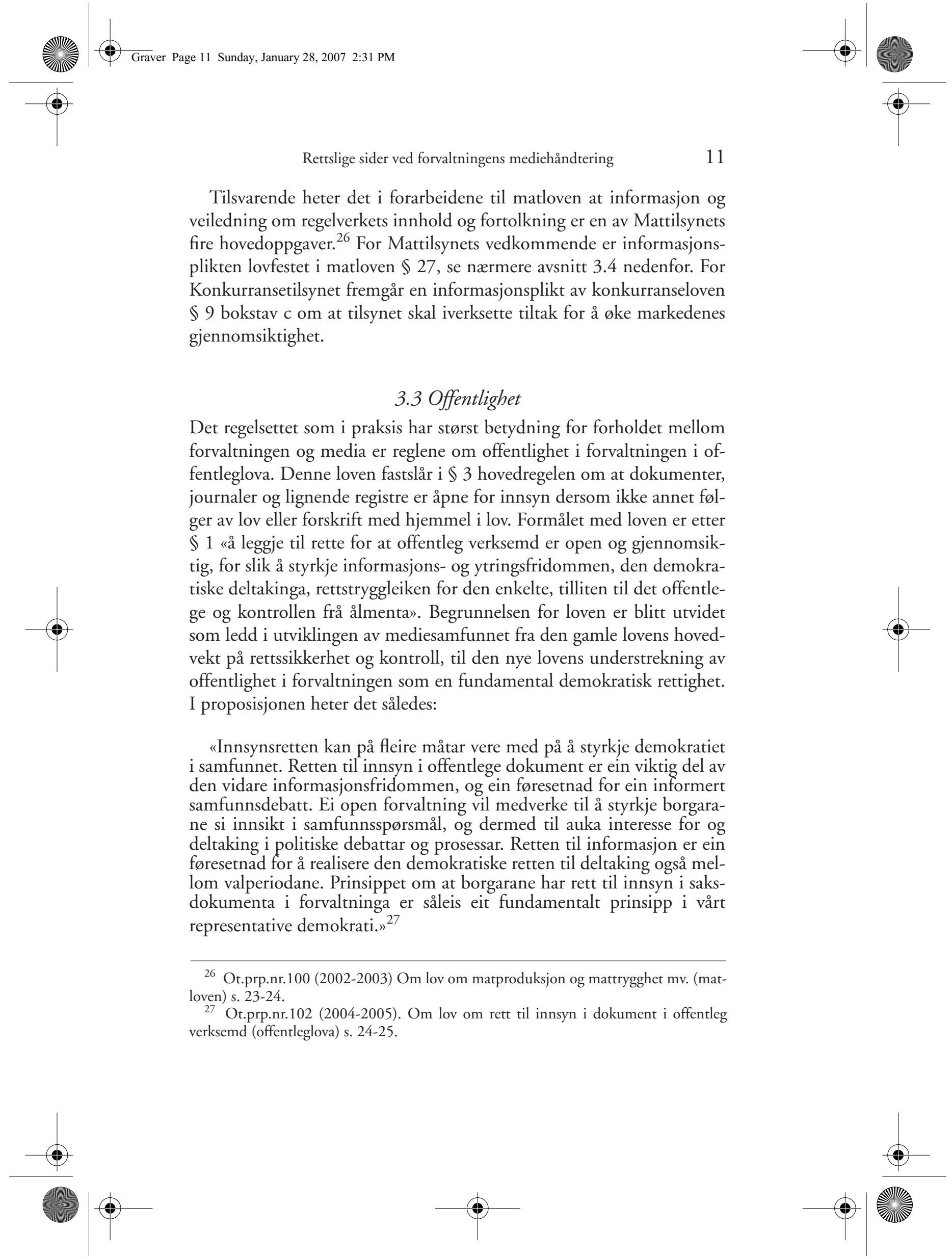
Offentlighetsloven regulerer direkte det man kan kalle en passiv offentlig informasjonsrolle ved at den gir regler om plikt til å gi innsyn etter forespørsel. I praksis vil imidlertid pressens bruk av denne retten bringe spørsmålet om forvaltningens aktive mediebruk på banen, fordi organet kan bli bedt om eller føle behov for å kommentere oppslag som blir gjort på grunnlag av innsyn i saksdokumenter. Det forhold at offentligheten har innsynsrett kan også være en begrunnelse for at et organ på eget initiativ går aktivt ut med informasjon om en sak. Dersom forvaltningen tror at en sak vil bli gjenstand for medieoppmerksomhet uansett, vil den kunne ønske å bestemme tidspunktet for og vinklingen av presentasjonen av en sak i offentligheten. Statens informasjonspolitikk fastlegger uttrykkelig at forvaltningen må være føre var i den forstand at informasjon om saker så langt som mulig bør skje i forkant av medienes interesse for dem. ${ }^{28}$

Hensynene bak offentlighetsprinsippet kan være en begrunnelse for at forvaltningen aktivt informerer også utover de saker hvor man regner med at pressen på eget initiativ vil ta opp en sak. Det samme gjelder ved vurderingen av om det skal praktiseres meroffentlighet. En begrunnelse som ofte brukes for ikke å gå ut offentlig fra forvaltningens side er at offentlighet kan hindre en fortrolig dialog internt og redusere forvaltningens handlefrihet. Ombudsmannen har i en sak om innsyn i sak om utlysing av blokker på norsk sokkel uttalt at «større åpenhet kan jo snarere sies å medføre at saken får en mer forsvarlig behandling. Jeg peker herunder på at større åpenhet vil kunne føre til at en slik sak - som har stor miljøog samfunnsmessig betydning - blir bedre opplyst ved at miljøorganisasjoner og allmennheten for øvrig også får anledning til å komme med innspill og delta i diskusjonen før regjeringen fatter sin avgjørelse.» ${ }^{29}$

\subsection{Taushetsplikt}

Reglene om taushetsplikt setter viktige rammer for spørsmålet om forvaltningens mediehåndtering. De sentrale reglene her er forvaltningsloven $\$ \$ 13 \mathrm{flg}$. Mange saker i media dreier seg om enkeltpersoner eller enkeltbedrifter som for eksempel er utsatt for offentlig tilsyn eller som

\footnotetext{
28 Informasjonspolitikk for statsforvaltningen, Arbeids- og administrasjonsdepartementet 2001 s. 8.

29 Sivilombudsmannens årsmelding 2005 s. 72.
}
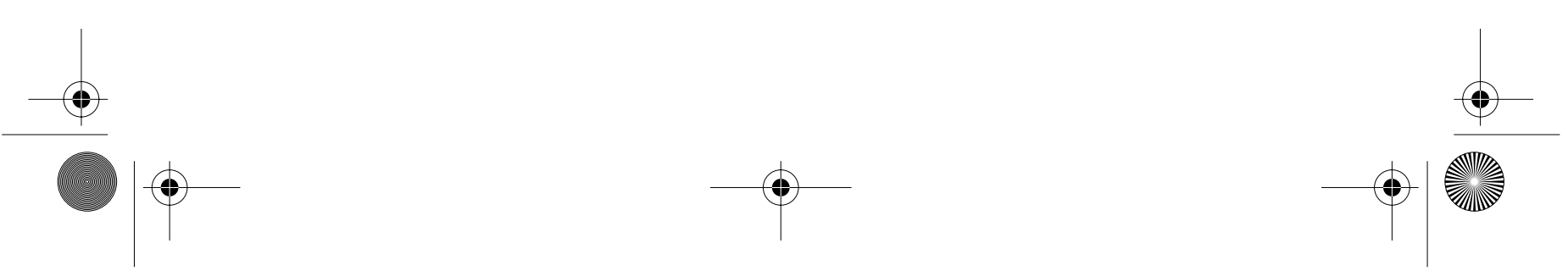
hevder seg utsatt for uriktig behandling av forvaltningen. Taushetspliktreglenes beskyttelse av opplysninger om personlige forhold eller forretningshemmeligheter utgjør absolutte skranker for hva forvaltningen passivt kan gi innsyn i eller aktivt gå ut med i offentligheten. Det knytter seg ofte stor offentlig interesse til slike saker, noe som gjør at taushetspliktreglene i praksis har stor betydning som ramme for forvaltningens informasjonsvirksomhet.

Man kan av og til få inntrykk av at taushetspliktreglene brukes av forvaltningen som beskyttelse mot offentlighet der tjenestemenn ikke ønsker å uttale seg om kritikk som fremsettes mot behandlingen av en sak. Det er vel kjent at taushetsplikt ikke alltid oppfattes som en tung plikt. Tradisjonelt har taushetsplikten også ofte vært strukket lengre enn det reglene selv gir dekning for. Dette kan også skyldes en frykt for å komme i ansvar overfor den som har krav på beskyttelse. Særlig kan dette gjelde taushetsplikten i forhold til forretningshemmeligheter.

Det nærmere innholdet av taushetspliktsreglene, herunder generelt om hva som må regnes som personlige forhold eller forretningshemmeligheter går jeg ikke nærmere inn på her. Det kan likevel være grunn til å minne om at opplysning som røper partsforhold $\mathrm{i}$ en forvaltningssak som hovedregel ikke anses som en opplysning om vedkommendes personlige forhold. ${ }^{30}$ Opplysning om at en person er anmeldt til politiet for et angivelig straffbart forhold må på den annen side anses som en taushetsbelagt personopplysning. ${ }^{31}$ En juridisk person, for eksempel en bedrift, har ikke vern etter bestemmelsen om taushetsplikt om personlige forhold. ${ }^{32}$ Dette kan være annerledes hvor foretaket drives som et personlig selskap, hvor opplysninger om bedriften samtidig er opplysninger om eieren personlig. ${ }^{33}$

Det kan diskuteres om juridiske personer burde ha et vern for «personlige» opplysninger på linje med fysiske personer. ${ }^{34}$ Et stykke på vei er dette behovet imøtekommet gjennom vernet av forretningshemme-

\footnotetext{
30 Se Lovadelingens uttalelse 12 august 1997 om klientforhold til arbeidsmarkedsetaten.

31 Se Tor-Geir Myhrer, Personvern og samfunnsansvar, Oslo 2001 s. 347-350.

32 Se også Geir Woxholth, Forvaltningsloven med kommentarer, tredje utg., Oslo 1999 s. 204.

33 Se til illustrasjon Sivilombudsmannens årsmelding 2001 s. 114.

34 Se f.eks- Lee A Bygrave, A right to privacy for corporations? Lenah in an international context, Privacy Law \& Policy Reporter, 2001, volume 8, pp 130-134.
}
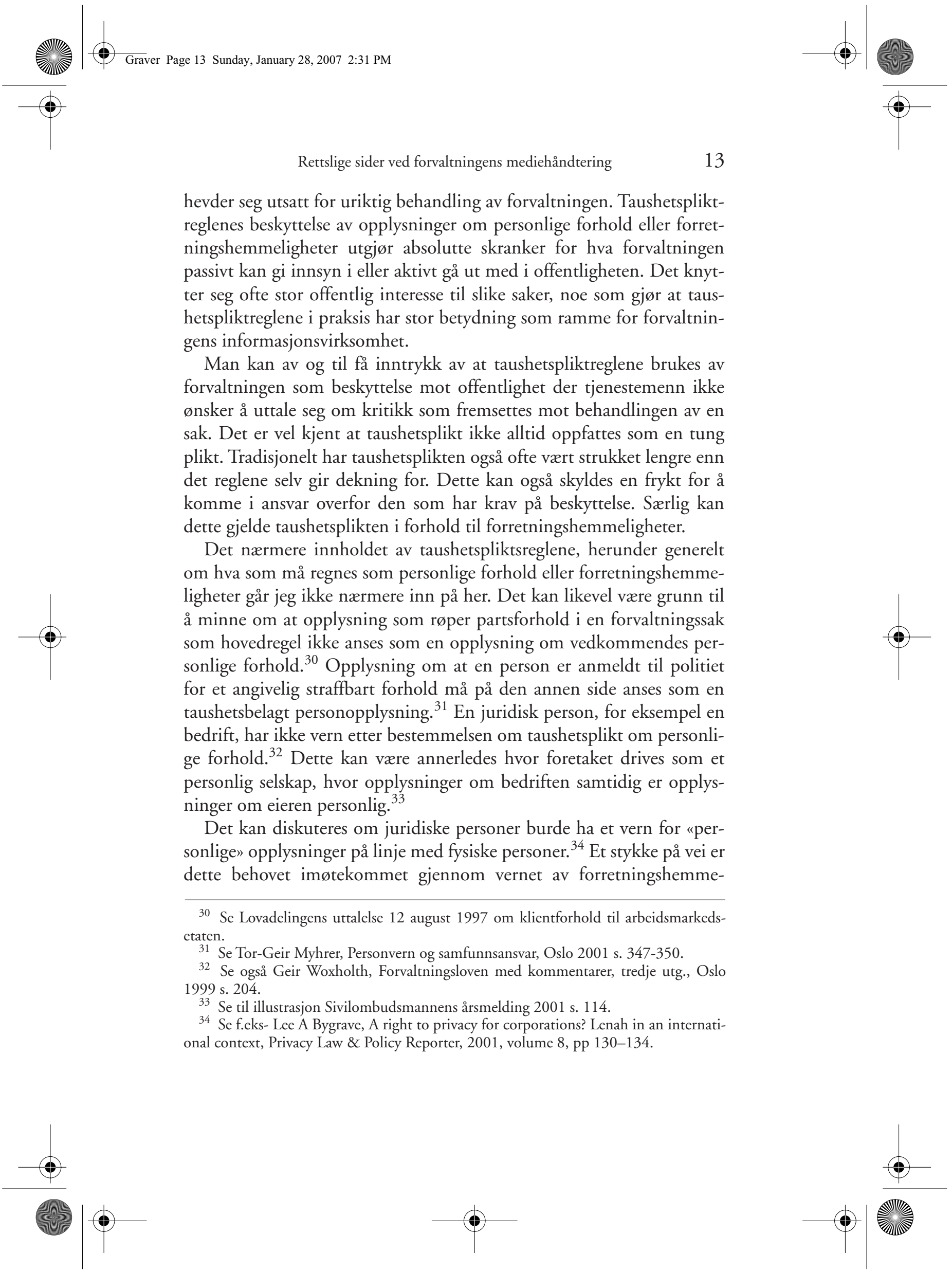
ligheter som både omfatter tekniske innretninger og fremgangsmåter samt drifts- eller forretningsforhold, dvs. opplysninger knyttet til teknologi, oppskrifter og know-how og kommersielle forhold som kundelister, leverandører, pris- og kostnadsforhold og fremtidige planer. ${ }^{35}$ Opplysninger om en bedrifts forbindelse med offentlige myndigheter, som for eksempel søknader, anmeldelse, inspeksjoner og pålegg fra offentlige tilsyn er ikke omfattet av regelen om beskyttelse av forretningshemmeligheter. Det samme er tilfelle med opplysninger om at en bedrift har mottatt støtte, og hvilket beløp som er mottatt. Heller ikke opplysninger som kan skade bedriftens omdømme, som for eksempel at den er anmeldt for rasediskriminering eller brudd på korrupsjonsbestemmelser, omfattes, selv om det kan skade bedriftens konkurranseposisjon at opplysningen blir kjent. ${ }^{36}$

I arbeidsrettslig sammenheng går arbeidstakeres rett til å varsle om kritikkverdige forhold i arbeidsmiljøloven $\$ 2$-4 foran plikten til å bevare taushet om bedriftshemmeligheter i snever forstand. ${ }^{37}$ Begrepet kritikkverdige forhold gjelder for det første opplysninger om kriminelle (dvs. straffesanksjonerte) forhold og mislighold av andre lovbestemte påbud eller forbud. Det samme gjelder brudd med virksomhetens etiske retningslinjer. Her bør det imidlertid være tale om rutiner som er tydelig uttalte og som er nedfelt i skriftlige dokumenter som er gjort kjent for ansatte og ledelse. I tillegg omfattes alminnelige etiske standarder som det er bred tilslutning til i samfunnet. ${ }^{38}$ Tilsvarende inneholder den svenske Lag om skydd för företagshemligheter (1990:409) et uttrykkelig unntak fra forbudet mot å offentliggjøre forretningshemmeligheter i $2 \$$ som sier at «som ett obehörigt angrepp anses inte att någon anskaffar, utnyttjar eller röjer en företagshemlighet hos en

35 Forretningshemmeligheter generelt omfatter alle fortrilige meddelelser, opplysninger og dokumenter m.v. knyttet til en virksomhets merkantile og tekniske forhold, se Mogens Koktvedtgaard, Immaterialretsposisjoner, København 1965 s. 296. Forvaltningsloven $₫ 13$ knytter beskyttelsen til at det «vil være av konkurransemessig betydning å hemmeligholde (opplysningen) av hensyn til den som opplysningen angår».

36 Lovavdelingen har i uttalelse av 19. november 1998 antatt at opplysninger om at en bedrift handler med Burma ikke er omfattet av forvaltningsloven $₫ 13$.

37 Se Ot.prp. nr. 84 (2005-2006) Om lov om endringer i arbeidsmiljøloven (varsling) hvor det settes frem forslag om nye lovregler som skal styrke ansattes reelle ytringsfrihet og vernet av de som ytrer seg s. 37

38 Jf. Ot.prp. nr. 84 (2005-2006) Om lov om endringer i arbeidsmiljøloven (varsling) s. 50 .
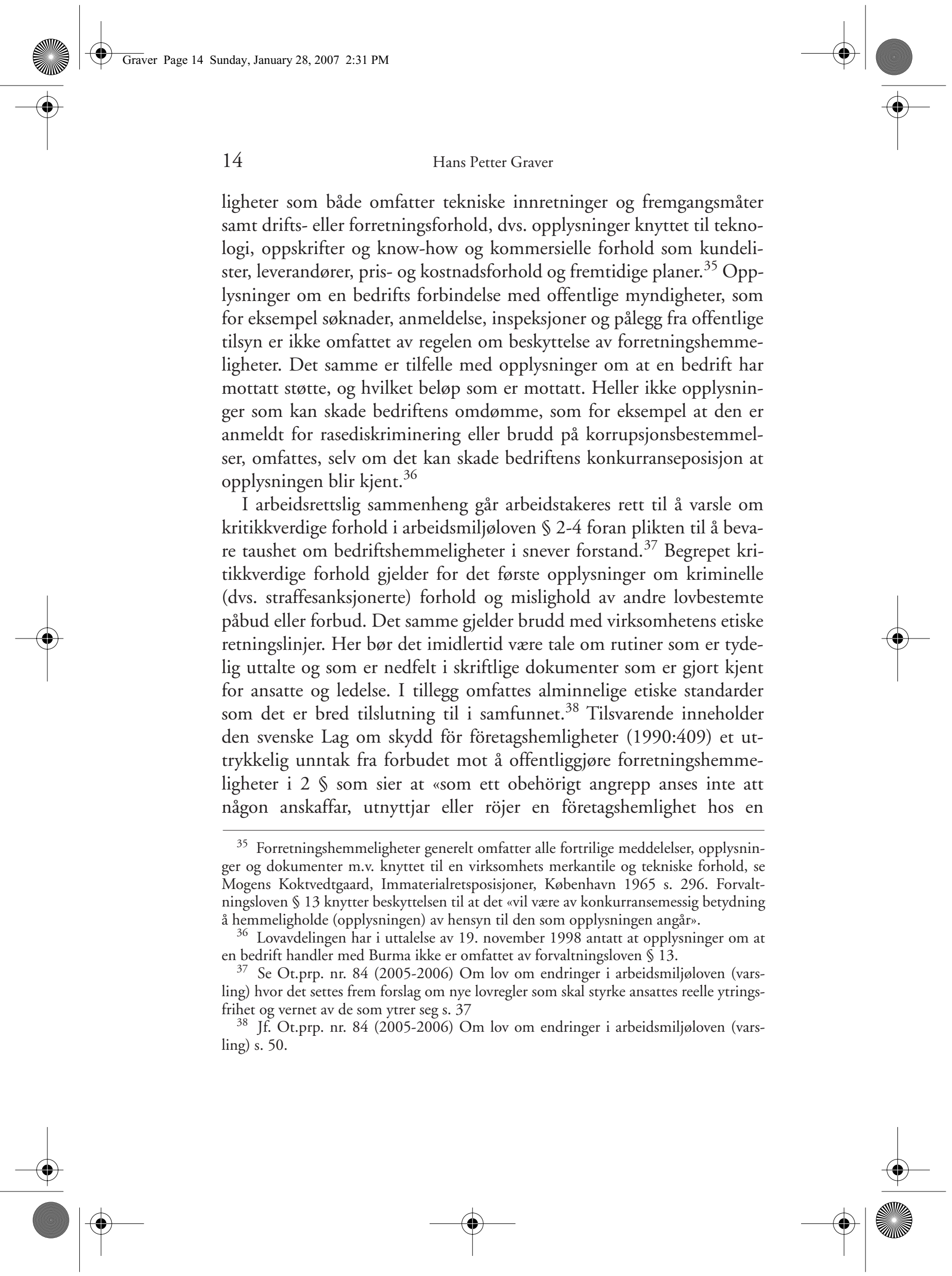
näringsidkare för att offentliggöra eller inför en myndighet eller annat behörigt organ avslöja något som skäligen kan misstänkas utgöra brott, på vilket fängelse kan följa, eller som kan anses utgöra annat allvarligt missförhållande i näringsidkarens rörelse.»

Det kan også være på sin plass å betone at reglene til en viss grad åpner for en avveining mellom hensynet til den som skal beskyttes av taushetsplikten og hensynet til almenhetens krav på innsyn og deltakelse i opplysninger knyttet til offentlig virksomhet og beslutninger. Opplysninger som gjelder en person, kan også si noe om omverdenens forhold til personen, og de hensyn som taler for åpenhet om dette, kan måtte veie tyngre enn personens egeninteresse i taushet. Ut fra en slik betraktning er det i praksis lagt til grunn at offentlige ansatte ikke nyter vern for opplysninger om deres tjenestelige forhold. Også rent frem belastende opplysninger om en offentlig tjenestemanns tjenestehandlinger vil lettere falle utenfor taushetsplikten enn opplysninger om tilsvarende handlinger foretatt av privatpersoner. ${ }^{39}$ Ombudsmannen har i en sak uttalt at «embetsledere må tåle at det rettes et kritisk søkelys mot embetets virksomhet. De offentlige ledere som er anmeldt for brudd på tjenesteplikter, må normalt også finne seg $\mathrm{i}$ at forvaltningens anmeldelser omtales offentlig.» ${ }^{40}$ At opplysninger knyttet til embetsførselen ikke kan anses som opplysninger om "personlige forhold" henger sammen med de forventninger som allmennheten med rette kan ha til offentlig tjeneste. Slike opplysninger vil derfor i utgangspunktet bare kunne regnes som personlige så langt opplysningene angår forhold av en slik art at de er egnet til å karakterisere vedkommende som person.

Samme betraktninger må være av betydning ved vurdering av vernet til personer som opptrer i andre viktige samfunnsposisjoner enn offentlige stillinger. Informasjon om maktutøvelsen i samfunnet og de formelle og uformelle maktutøvere innen politikken, økonomien og samfunnet for øvrig utgjør offentlighetsprinsippets og ytringsfrihetens kjerneområde. ${ }^{41}$ Sanksjonsutvalget fremhever at man må skille mellom

39 Se uttalelse fra Lovavdelingen 19. november 1998 med videre henvisninger til egen praksis og uttalelser fra Sivilombudsmannen.

40 Sivilombudsmannens årsmelding 2002 s. 79.

41 Se Tor-Geir Myhrer, Personvern og samfunnsansvar, Oslo 2001 s. 242-245 som likevel mener at det på grunn av forarbeidene er vanskelig å infortolke en slik interesseavveing i loven.
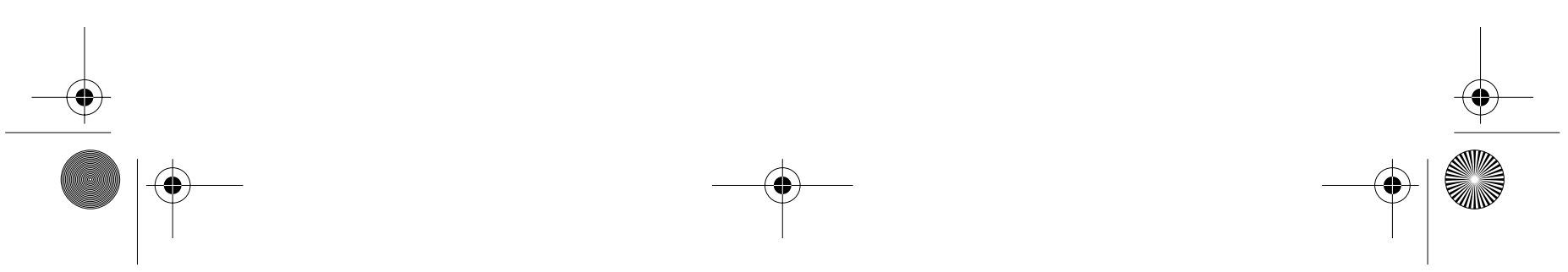
belastende forhold knyttet til forhold som gjelder generelt for private borgere og overtredelser av regler for profesjonelle eller næringsdrivende innen et gitt område hvor vedkommende "frivillig» har innlatt seg på å drive en virksomhet underlagt særlige bestemmelser. ${ }^{42}$ I praksis synes verken Justisdepartementets lovavdeling eller Sivilombudsmannen å godta som generell regel at næringsdrivende eller innehavere av en offentlig tillatelse er ikke beskyttet av taushetsplikten mot at belastende forhold knyttet til deres virksomhet gjøres kjent. ${ }^{43}$ At det må foretas en interesseavveining slik at opplysninger knytte til profesjonell eller forretningsmessig virksomhet ikke kan regnes som personlig der saken har offentlig interesse, har likevel gode grunner for seg.

Ytringsfrihetskommisjonen fremholder at det er allment godtatt at «offentlige personer», dvs. personer med sosial makt, enten denne har sin basis i politikken eller i offentlige eller private institusjoner, må finne seg i en større grad av offentliggjøring av sitt privatliv enn vanlige mennesker. Selv om også disse har krav på et skille mellom den private og den offentlige sfære, kan det oppstå et legitimt behov for noe større innsikt $\mathrm{i}$ offentlige personers privatliv enn i privatlivet til vanlige mennesker. Det må også skilles mellom opplysninger fra privatlivet og personlige egenskaper. Det siste er det naturligvis helt legitimt å spørre etter hos mennesker med makt. Og det er blant annet dette behov for å vite om deres personlige egenskaper, som kan legitimere en viss adgang til å vite noe om deres private liv. Det er også legitimt å spørre etter forhold som har med deres faktiske maktutøvelse å gjøre, eller som reflekterer strukturelle forhold i samfunnet. Det dreier seg om det grunnleggende argument at åpenhet er viktig for å skape tillit og mulighet for kontroll. $^{44}$

Det finnes regler i andre lover som uttrykkelig åpner for avveininger som fører til at beskyttelseshensynene må vike i større utstrekning enn det som følger av de alminnelige regler i forvaltningsloven $\$ 13$. Her kan vises til miljøinformasjonsloven $₫ \$ 11$ og 12 . Etter $₫ 12$ skal krav om miljøinformasjon som dreier seg om helseskadelig forurensning eller forurensning som kan forårsake alvorlig skade på miljøet, forholdsregler for å hin-

42 NOU 2003:15 Fra bot til bedring s. 87.

43 Se f.eks. Sivilombudsmannens årsmelding 2001 s. 114 om bl.a. Konkurransetilsynets offentliggjøring av anmeldelse der navn på de anmeldte enkeltpersoner går frem.

${ }^{44}$ Se NOU 1999:27 «Ytringsfrihed bør finde Sted» s. 112.
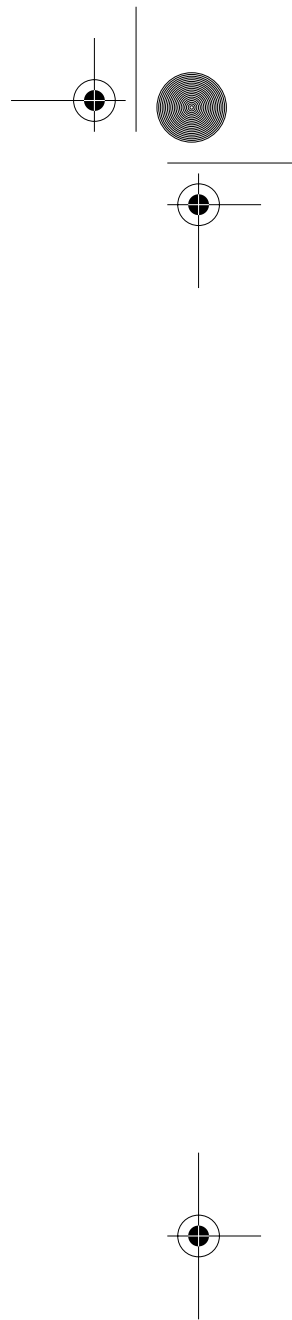
dre eller redusere slik skade og opplysning om ulovlige inngrep i eller ulovlige skader på miljøet alltid utleveres, selv om det dreier seg om forhold som ellers ville gått inn under regler om taushetsplikt. I praksis vil det likevel sjelden være konflikt mellom denne bestemmelsen og taushetspliktreglene. At en bedrift har overtrådt miljøbestemmelser eller skadet miljøet kan ikke anses som en forretningshemmelighet selv om det er skadelig for bedriften at dette blir kjent, og når enkeltpersoner er ansvarlig må opplysningene anonymiseres så langt det er mulig. ${ }^{45}$ Der hvor det blir konflikt med taushetsplikten, skal den fortolkes restriktivt og forstås slik at bestemmelsen er ment å reserveres for spesielle tilfeller. ${ }^{46}$

Miljøinformasjonsloven $\$ 11$ har større rekkevidde, og åpner generelt for at det skal foretas en avveining mellom de miljø- og samfunnsmessige interessene som ivaretas ved å utlevere informasjonen, veies mot de interessene som ivaretas ved et avslag. Regelen gjelder også der interessene til den opplysninger angår har vern etter taushetspliktregler. Taushetsplikten har derfor ikke noe absolutt forrang fremfor almenhetens rett til miljøinformasjon.

Loven inneholder særlige saksbehandlingsregler som skal følges for å gi opplysninger som er omfattet av taushetsplikt. Jeg går ikke nærmere inn på disse her. ${ }^{47}$

Et annet eksempel er konkurranseloven $₫ 22$ som pålegger Konkurransetilsynet å offentliggjøre sine vedtak, og som bestemmer at opplysninger underlagt taushetsplikt etter forvaltningslovens regler om forretningshemmeligheter «kan offentliggjøres dersom det er nødvendig for å opplyse om vedtakets hovedinnhold». Begrunnelsen for regelen om offentliggjøring av vedtak er at dette vil tydeliggjøre den samfunnsmessige avveiningen mellom de skadelige virkninger for konkurransen og andre samfunnsmessige hensyn. Dette vil kunne skape grunnlag for en offentlig debatt. Det vil også sette markedsaktørene i stand til å tilpasse seg reguleringer mellom ervervsdrivende for å unngå virkningene av dem og skape større gjennomsiktighet og bevisstgjøre etterspørrere, særlig med hensyn til forhold omkring priser og andre forretningsvilkår. ${ }^{48}$

\footnotetext{
45 Se NOU 2001:2 Retten til miljøopplysninger s. 152.

46 Se Sigrid Anderssen Cabot, Miljøinformasjonslova - overblikk og kommentar, Oslo 2005 s. 171.

47 Se for en oversikt Sigrid Anderssen Cabot op. cit. s. 181-194.

48 Se NOU 2003:12 Ny konkurranselov s. 42-43.
}
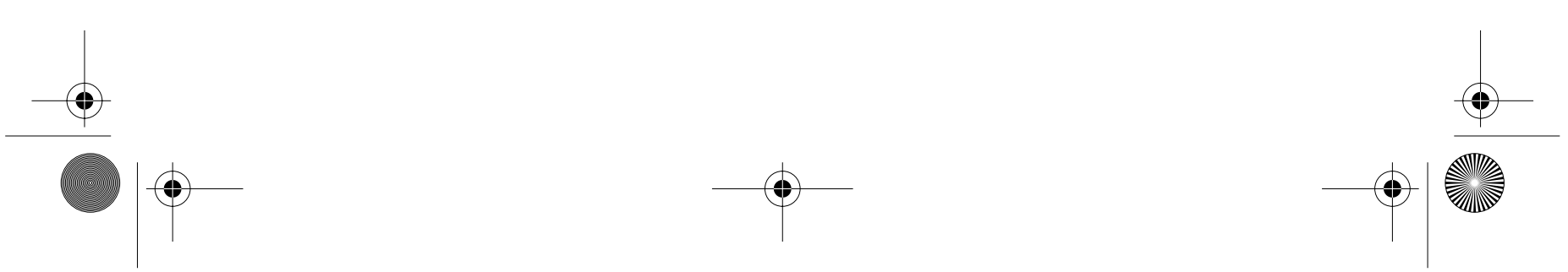
Det skal forholdsvis mye til før det etter bestemmelsen kan være adgang til å offentliggjøre opplysninger som omfattes av taushetsplikten. Som hovedregel bør Konkurransetilsynet og departementet lage en offentlig versjon der de taushetsbelagte opplysningene er fjernet. ${ }^{49}$

Også konkurranseloven $₫ 27$ om innsyn i dokumenter hos konkurransemyndighetene åpner for at taushetsbelagte opplysninger gjøres kjent for andre. Bestemmelsen gir enhver med «rettslig interesse» adgang til å kreve innsyn i dokumenter hos konkurransemyndighetene $\mathrm{i}$ en avsluttet sak om overtredelse av loven. Dette gjelder også dokumenter som inneholder opplysninger som er underlagt lovbestemt taushetsplikt. I slike tilfelle kreves det at innsyn ikke vil virke urimelig overfor den opplysningene gjelder. Det må foretas en konkret vurdering av om opplysningene bør gis ut. Konkurransetilsynet må ta hensyn til den ervervsdrivendes berettigede interesse $\mathrm{i}$ å bevare sine forretningshemmeligheter. Tilsynet må derfor vurdere de hensyn som taler for offentliggjøring opp mot den næringsdrivendes interesse i at opplysningene ikke kommer ut. En slik avveining må ikke bare foretas i forhold til spørsmålet om opplysninger skal gis ut, men også når det vurderes hva som eventuelt skal gis ut og hvordan dette skal skje. ${ }^{50}$ Bestemmelsen gir ikke tilsynet hjemmel til å offentliggjøre opplysninger på eget initiativ. Når opplysninger først er gitt ut til en med rettslig interesse, kan de imidlertid neppe lenger karakteriseres som «hemmelige», og vil av den grunn ikke lenger være undergitt taushetsplikt.

Matloven $₫ 27$ fastsetter at Mattilsynet på eget initiativ skal gi allmennheten relevant informasjon som den er i besittelse av ved mistanke om at det kan oppstå fare for menneskers ellers dyrs helse knyttet til inntak av næringsmidler eller fôr. Tilsynet kan videre gi relevant informasjon til allmennheten når forbruker- eller andre samfunnshensyn taler for det. Det stilles ikke krav om en alvorlig helsefare. Helsefaren må være aktuell, jf bestemmelsene om fôr- og næringsmiddeltrygghet. Det er heller ikke noe krav om at den eventuelle helsefaren skal utgjøre en fare for mange. Det er nok at det foreligger rimelig grunn til fare for no-

\footnotetext{
49 Se Ot.prp.nr.6 (2003-2004). A) Om lov om konkurranse mellom foretak og kontroll med foretakssammenslutninger (konkurranseloven)

B) Om lov om gjennomføring og kontroll av EØS-avtalens konkurranseregler mv. (EØS-konkurranseloven) s. 234.

50 Se Sivilombudsmannens årsmelding 2001 s. 114.
}
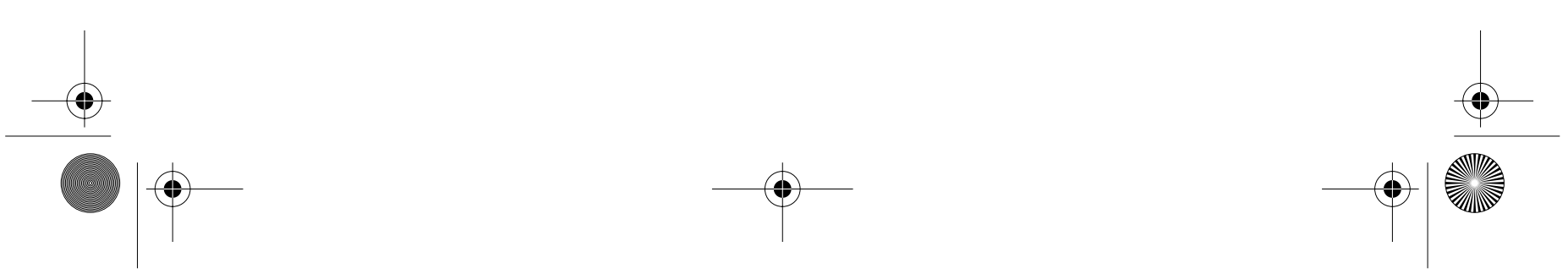
en, f.eks. at det er funnet nøtter $\mathrm{i}$ et næringsmiddel uten at dette fremgår av merkingen, eller at et næringsmiddel inneholder stoffer som kan være skadelig for gravide. Tilsynsmyndigheten skal ikke gi informasjon om opplysninger tilsynsmyndigheten har som vil avdekke forretningsmessige forhold eller taushetsbelagte opplysninger om virksomheten med mindre disse opplysningene er nødvendig for å unngå fare for menneskers eller dyrs helse. ${ }^{51}$

\section{Krav til saksbehandlingen ved omtale som ramme bestemte personer}

\subsection{Innledning}

Som nevnt overfor, bruker mange organer omtale av enkeltsaker som virkemiddel for å spre informasjon om innholdet av de regler de forvalter. Slik omtale er også ledd i et generelt holdnings- og legitimitetskapende arbeid ved å skape oppmerksomhet og interesse om organets oppgaver, synliggjøre dets virksomhet i samfunnet og skape forståelse for hva det gjør og hvorfor.

Forvaltningen omtaler også enkeltsaker for å imøtekomme offentlighetens behov for kunnskap. Informasjon fra det offentlige er ofte en forutsetning for at folk på en meningsfull måte skal kunne holde seg underrettet fra pålitelige kilder. Saker som har store eller dramatiske konsekvenser, eller som angår parter som gjennom sin posisjon eller virksomhet er gjenstand for oppmerksomhet er ofte gjenstand for stor offentlig interesse. Av hensyn både til demokrati, ytringsfrihet og retten til å bli informert vil forvaltningen ha en forpliktelse til å informere og vise åpenhet i slike saker.

Enkeltsaker blir ofte tema i offentligheten på initiativ fra andre enn forvaltningen selv. Det kan være pressen som bruker innsynsretten etter offentlighetsloven, eller parter, konkurrenter eller andre som initierer omtalen som ledd i sin kommunikasjonsstrategi.

Uansett bakgrunnen for at en enkeltsak omtales, kan en slik omtale ofte være en belastning for den som er part i saken eller som av andre

51 Se Ot.prp.nr.100 (2002-2003) Om lov om matproduksjon og mattrygghet mv. (matloven) s. 163.
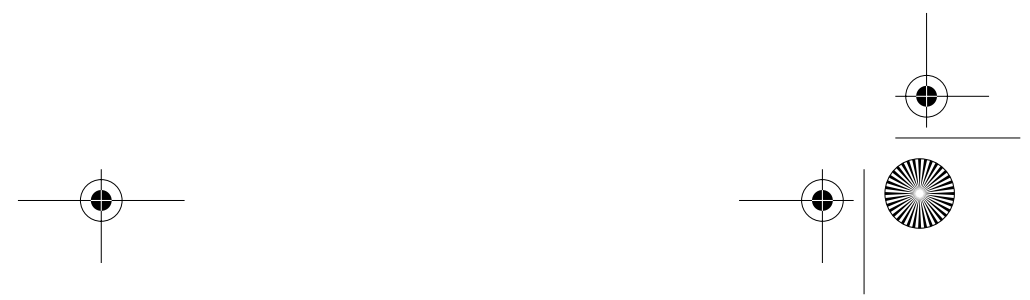
grunner blir gjenstand for omtale. Offentlig informasjon kan også ramme enkeltpersoner eller -bedrifter uten at det er snakk om direkte omtale. For eksempel kan turoperatører bli rammet av omsetningssvikt dersom UD går ut med advarsel mot å reise til et bestemt land på grunn av terrorfare.

Siden offentlig informasjon kan være belastende, kan man spørre om det gjelder noen krav til forvaltningen før den går ut med omtale av individuelle personer. Avgjørelse om å omtale noen eller gi informasjon til almenheten er ikke enkeltvedtak i forvaltningslovens forstand. Derfor gjelder ikke forvaltningslovens bestemmelser om enkeltvedtak. Det er heller ingen regler i offentleglova som gir rettigheter til den som er omtalt $i$ et dokument som det søkes innsyn i, med mindre det dreier seg om opplysninger underlagt taushetsplikt. Er det snakk om taushetsbelagte opplysninger, skal spørsmålet om å gi innsyn i dem forelegges den som har krav på taushetsplikt, dersom taushetsplikten er av en slik art at den bortfaller ved dennes samtykke, se offentleglova $₫ 13$ tredje ledd. Svarer ikke vedkommende innen den fastsatte fristen, skal det oppfattes som avslag. Dersom det er snakk om opplysninger som det kan være berettiget grunn til tvil om er taushetsbelagte eller ikke, kan gode grunner tilsi et spørsmålet om offentliggjøring forelegges den som eventuelt har krav på taushet. I en sak om Konkurransetilsynets overlevering av opplysninger om en bedrift til dens kunder, uttalte ombudsmannen:

«I grensetilfelle kan det være vanskelig å avgjøre hvilke opplysninger som det er av konkurransemessig betydning å hemmeligholde. Ofte kan den som opplysningene angår, bidra til å klargjøre om opplysningene kan ha konkurransemessig betydning. Det kan derfor i vanskelige saker være i best samsvar med god forvaltningspraksis å be bedriften om dens syn på spørsmålet.» ${ }^{52}$

Utover dette må eventuelle rettigheter til den som gjenstand for omtale og eventuelle krav til forvaltningens behandling bygges på uskrevne prinsipper og regler. Utgangspunktet for vurderingen må være at næringsdrivende og andre "på samme måte som de i vid utstrekning er nødt til å avfinne seg med medias og andres til dels urettferdige og skånselsløse «informasjon» om deres produkter og tjenester - må leve med

52 Sivilombudsmannens årsmelding 2001 s. 114.
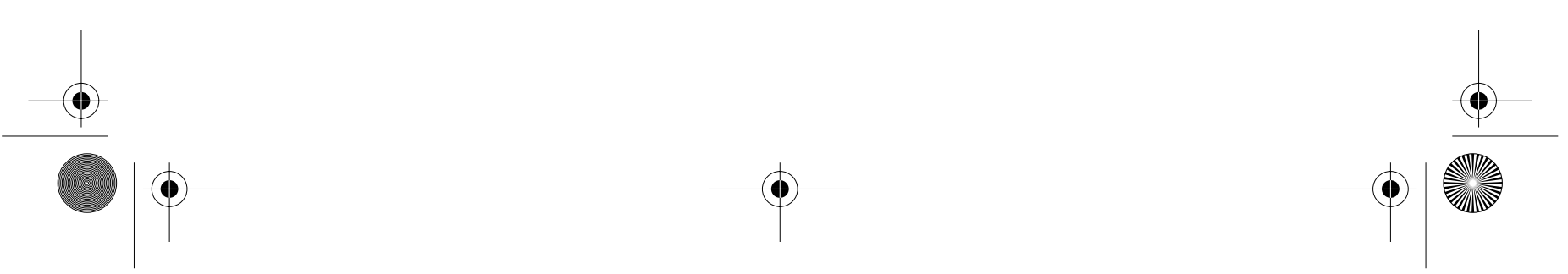
den risiko det er at de offentlige myndigheter skal gi informasjon og råd til borgerne». ${ }^{53}$ Lovfestingen av offentlighet i forvaltningen innebærer at lovgiveren allerede har foretatt interesseavveingen i favør av offentlighet også der dette kan skade private interesser. Det er derfor bare rent unntaksvis at det kan bli tale om å oppstille rettigheter i forhold til forvaltningens mediehåndtering.

Omtale av bedrifter eller personer vil ofte skje i forbindelse med en sak forvaltningen behandler eller har behandlet med sikte på å treffe vedtak. Omtalen kan skje når en sak settes i gang, når forvaltningen gir varsel om at den vurderer å treffe et vedtak og etter at et vedtak er truffet. I noen tilfeller an det også forekomme at en bedrift eller person er gjenstand for omtale uten at det skjer i forbindelse med behandlingen av en sak, for eksempel der et organ går ut med informasjon til publikum for å komme et konkret behov i møte.

Både de hensyn som ligger til grunn for offentlighet og for tilbakeholdenhet, og de krav som må stilles til forvaltningen vil være avhengig av om omtalen skjer i forbindelse med behandlingen av en enkeltsak, og i tilfelle på hvilket stadium av saksbehandlingen omtalen skjer. I tillegg kan det selvsagt alltid stilles krav til måten omtalen vinkles på i forholdet til det grunnlaget forvaltningen har til å uttale seg på.

\subsection{Omtale av forvaltningens vedtak}

Vedtak forvaltningen har truffet vil det sjelden være grunn til ikke å omtale med mindre lang tid er gått. Opplysninger gitt i begrunnelsen for vedtaket vil være resultat av forvaltningens saksbehandling. De vil derfor regelmessig ha vært forelagt partene som ledd i saksforberedelsen og representere forvaltningens standpunkter etter en kontradiktorisk behandling. Dersom en part mener at de er uriktige eller misvisende, er det som regel selve vedtaket parten er misfornøyd med. Parten får i så fall angripe vedtaket, ikke forvaltningens omtale av det. Det er neppe grunn til å stille særlige krav til forvaltningens omtale utover det generelle om at den må være saklig og dekkende i forhold til det som står i vedtaket.

53 Viggo Hagstrøm, Det offentliges ansvar for feilaktig informasjon i Festskrift til Carl August Fleischer, dog Fred er ej det Bedste, Oslo 2006 s. 217-224.
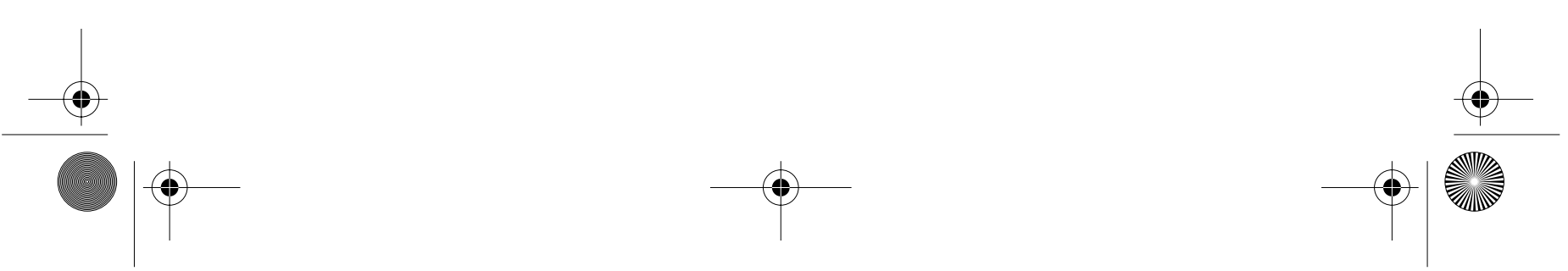
Noen særspørsmål kan likevel reises. For det første kan det tenkes at en er part ikke er misfornøyd med vedtaket som sådan, men samtidig mener at noe av det som står i begrunnelsen er feil. Det er etter forvaltningsloven ikke adgang til å klage på begrunnelsen i et vedtak. Likevel må det være avgjørende at parten har hatt muligheter til kontradiksjon under forvaltningens behandling, slik at det ikke kan være grunn til å innrømme noen rett til å komme med innsigelser mot at slike forhold nevnes av forvaltningen i forbindelse med en offentlig omtale.

Et annet spørsmål er om forvaltningen har taushetsplikt om vedtak som det kan være belastende for parten at blir kjent. Vedtak som ikke kan offentliggjøres uten å røpe klientforhold eller andre personlige forhold som for eksempel helseopplysninger eller vedtak om sosialstøtte eller omsorgsovertakelse, vil selvsagt være taushetsbelagte. Annerledes kan det være hvor vedtaket går ut på å konstatere at en person har gjort noe klanderverdig eller ulovlig, for eksempel vedtak om å ilegge en sanksjon eller tilbakekalle en tillatelse. Det kan i den forbindelse trekkes en parallell til strafferetten, se bl.a. straffeprosessloven $₫ 28$ annet ledd om straffedommers offentlighet. Noen tilsvarende uttrykkelig bestemmelse om at forvaltningens vedtak uten videre er offentlige har vi ikke. Som regel vil vedtaket likevel være offentlig etter offentleglovas alminnelige regel.

Etter den gamle loven kunne vedtak i saker om lovovertredelse unntas etter offentlighetsloven $₫ 6 \mathrm{nr}$. 5 som «dokument om lovovertredelse». Etter den nye offentleglova er det ikke uten videre adgang til å unnta «dokument om lovovertredelse». Loven setter i $₫ 24$ som vilkår at «innsyn ville motverke offentlege kontroll- eller reguleringstiltak eller andre pålegg eller forbod, eller føre til fare for at dei ikkje kan gjennomførast». For andre dokumenter enn tips o.lign. fra private, kan det som hovedregel bare gjøres unntak fra offentlighet inntil saken er avgjort, se bestemmelsens annet ledd. Det betyr at vedtak om å sanksjonere lovbrudd ikke lenger som etter den gamle loven generelt kan unntas fra offentlighet.

Som nevnt ovenfor vil opplysninger om klanderverdige forhold knyttet til en person i mange tilfelle gå inn under begrepet «personlige forhold» i forvaltningsloven $\$ 13$. Ombudsmannen har i en sak om politiets opplysning om at en person har fått inndratt sitt våpenkort etter våpenloven $₫ 10$ uttalt:
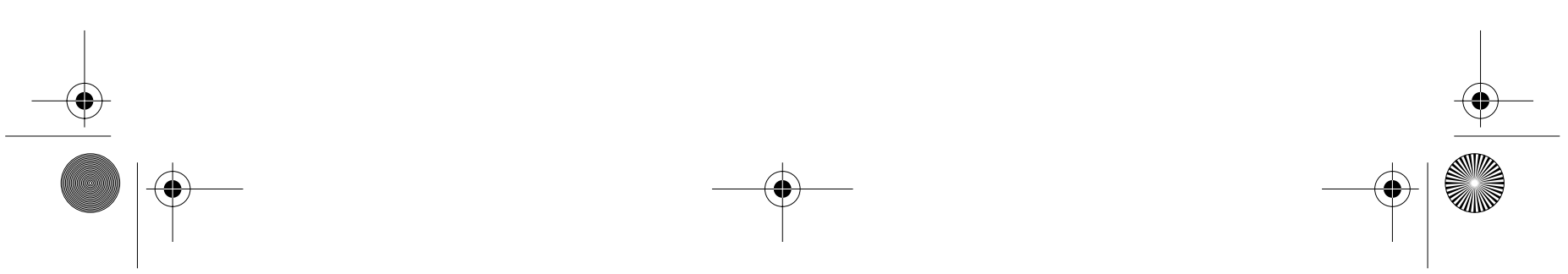
«Bestemmelsen gir anvisning på en vurdering av utpregede personlige forhold før våpenkortet tilbakekalles. Det kan ikke være tvilsomt at opplysninger om grunnlaget for tilbakekallingen av våpenkortet etter våpenloven $\$ 10$ normalt vil måtte regnes som « personlige forhold ». Opplysninger om at våpenkortet er tilbakekalt vil i seg selv ikke si noe nærmere om hva som er grunnlaget for tilbakekallet, men etter min mening vil også en slik opplysning måtte regnes som "personlige forhold ", særlig sett hen til de mulige aktuelle underliggende forhold.» ${ }^{54}$

Dette innebærer at taushetsplikten kan være til hinder for at vedtak offentliggjøres eller omtales av forvaltningen i offentligheten uten at vedtaket anonymiseres.

Sanksjonsutvalget mener at vedtak om ilagt administrativ sanksjon ikke generelt kan anses underlagt taushetsplikt etter regelen om beskyttelse av opplysninger om personlige forhold..$^{55}$ Utvalgets oppfatning går dermed tilsynelatende lengre i tillate offentlighet enn bl.a. den siterte uttalelsen fra ombudsmannen. Etter mitt syn går sanksjonsutvalget for langt i uten lovhjemmel å hevde at opplysning om at det er truffet et infamerende vedtak ikke er underlagt taushetsplikt. På den annen side er det så mange unntak fra taushetsplikten bl.a. av hensyn til å beskytte publikum og av hensyn til individual- og almenprevensjon at forskjellene i oppfatning i praksis ikke behøver få stor betydning.

Det er ikke slik at taushetsplikten alltid vil stenge for en omtale. Selv der det dreier seg om vedtak som er personlig belastende for den det gjelder kan reglene åpne for offentlighet. For det første minner jeg om det som er sagt ovenfor om at juridiske personer ikke er vernet mot belastende omtale, og at personer som innehar fremskutte posisjoner innen for eksempel politikk, forvaltning eller næringslov ikke har vern for omtale av forhold som har betydning for utøvelsen av denne posisjonen. I tillegg kan det fremgå av uttrykkelig lovbestemmelse at taushetsplikten må vike for hensynet til offentligheten som i miljøinformasjonsloven og matloven.

Dernest vil i praksis ofte regelen i forvaltningsloven $₫ 13$ a nr. 3 om taushetsplikten ikke gjelder forhold som er alminnelig kjent eller alminnelig tilgjengelig andre steder, åpne for omtale av vedtaket. Det kan for eksempel tenkes at det underliggende forhold er at parten er straffet. Si-

54 Sivilombudsmannens årsmelding 2005 s. 221.

55 Se NOU 2003:15 Fra bot til bedring s. 89
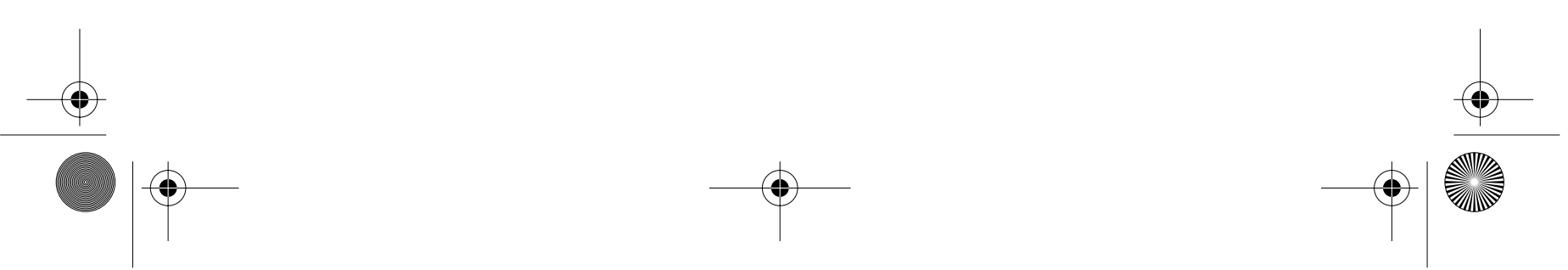
den straffedommer er offentlige, vil ikke forvaltningens etterfølgende behandling være underlagt taushetsplikt. Det kan også tenkes at det fra før gjennom medieomtale er kjent at forvaltningen behandler saken. Det spiller i denne forbindelse ingen rolle om årsaken til at opplysningene er kjent er brudd på taushetsplikt. ${ }^{56}$ Det som er vernet av bestemmelsene om taushetsplikt er fortroligheten, ikke det forhold at det er belastende å bli omtalt. At det er kjent at forvaltningen behandler en sak innebærer riktignok ikke at det er kjent hva utfallet av forvaltningens behandling blir. Opplysning om dette kan likevel som regel ikke anses som opplysning om et "personlig forhold». Det som er personlig er tilknytningen mellom en bestemt person og forvaltningens behandling, og det er jo nettopp kjent på forhånd.

Til illustrasjon kan nevnes en sak fra ombudsmannen om pressens innsyn i en benådningssak. Han kom til at utfallet av forvaltningens behandling ikke var underlagt taushetsplikt ut fra følgende begrunnelse: «Selv om det i utgangspunktet er forhold som er inntruffet etter dommen eller forhold som ikke var kjent på domstidspunktet som kan gi grunnlag for benådning, vil - som klageren har påpekt - likevel benådning også kunne oppfattes som en omgjøring av straffen. Den straffedømte slipper å sone en ilagt straff. Jeg er derfor tilbøyelig til å mene at det må tillegges noe vekt ved taushetspliktsvurderingen at dommen er offentlig. Det kan derfor få betydning med hensyn til hvilken grad av beskyttelse den domfelte har krav på. Ut fra tilliten til forvaltningen er det også viktig at slike opplysninger er offentlige slik at det kan føres en viss kontroll med forvaltningens benådninger.. 57

Et annet unntak fra taushetsplikten som kan gi adgang til å omtale vedtaket, er at taushetsplikt ikke er til hinder for at opplysningene brukes for å oppnå det formål de er gitt eller innhentet for. Opplysningene kan bl.a. brukes i forbindelse gjennomføring av avgjørelsen, oppfølging og kontroll. Treffes en avgjørelse om å tilbakekalle en offentlig tillatelse eller om å sanksjonere en virksomhetsutøver, må offentligheten kunne informeres om dette hvis det er nødvendig for å gjennomføre avgjørelsen. Hensynene bak den aktuelle reguleringsordningen kan tilsi at publikum informeres om forhold som har betydning for deres vurderinger

\footnotetext{
56 Se Sivilombudsmannens årsmelding 2002 s. 79.

57 Se Sivilombudsmannens årsmelding 2005 s. 67.
}
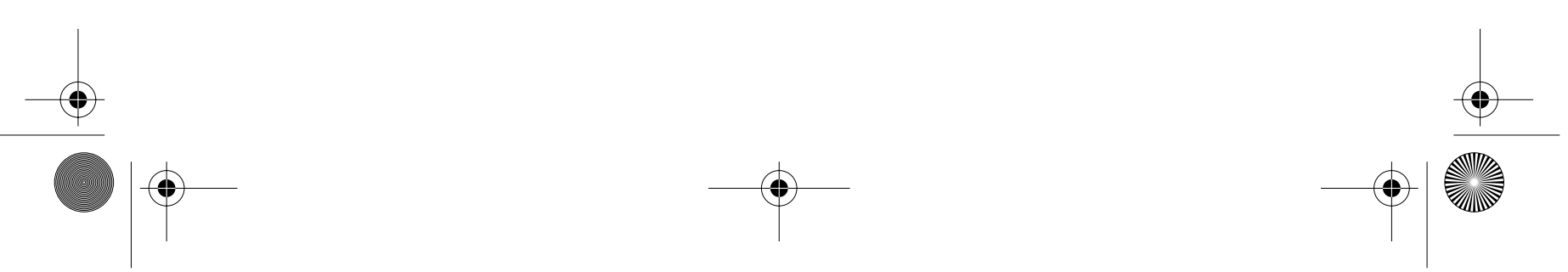
og bedømmelser av den som er ilagt en reaksjon. Til illustrasjon kan vi se på ombudsmannens uttalelse om Kredittilsynets offentlige kunngjøring av et eiendomsmeglerfirma drev virksomhet uten at den daglige leder hadde nødvendig bevilling og uten at det var stilt nødvendig sikkerhet for virksomheten. ${ }^{58}$ Videre kan hensynet til individual- og almenprevensjon tilsi at offentlighet om vedtaket er nødvendig for å oppnå formålet med forvaltningens behandling av saken. For eksempel uttaler departementet i forarbeidene til helsepersonelloven at et vedtak om advarsel overfor helsepersonell og de faktiske forhold som ligger til grunn for vedtaket bl.a. på dette grunnlag er undergitt offentlighet. «Derimot vil de underliggende forhold kunne være unntatt offentlighet dersom disse er av personlig karakter. At en uaktsom handling skyldes for eksempel personlige forhold som psykiske problemer, rusmiddelmisbruk, sosiale eller familiemessige problemer hos helsepersonellet er taushetsbelagt». 59

\subsection{Omtale for vedtak er truffet}

Før forvaltningen treffer sitt vedtak kan det være grunn til større tilbakeholdenhet i forholdet til offentligheten. I andre saker enn overtredelsessaker er det er ikke hjemmel i loven for å unnta et dokument som for eksempel et forhåndsvarsel med den begrunnelse at saken ikke er ferdigbehandlet. Dette betyr at de hensyn som tilsier at forvaltningen går ut med informasjon om innholdet av vedtak også kan tilsi en aktiv informasjon om varsel om vedtak der det kan forventes offentlig interesse om saken.

Når det gjelder det saker som bygger på forhold som kan være belastende for en fysisk eller juridisk person er dette annerledes. Offentlighetslovutvalget uttalte at

«særlig i forhold til dokumenter på et innledende stadium i saker der det er spørsmål om å avdekke og eventuelt sanksjonere lovovertredelser, kan det være uklart om det er begått noen lovovertredelse og hvor alvorlig overtredelsen i tilfelle er. Faren for at de dokumenter som foreligger

58 Sivilombudsmannens årsmelding 1991 s. 98.

59 Ot.prp.nr.13 (1998-1999) Om lov om helsepersonell m v (helsepersonelloven) $s_{\text {之 }}$
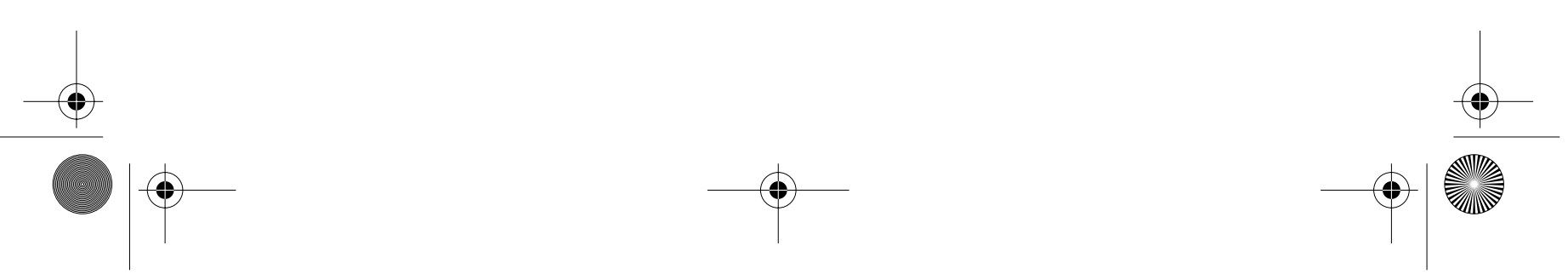
på et tidlig stadium i saken kan gi et uriktig eller misvisende bilde, taler dermed mot offentliggjøring på dette stadiet.. ${ }^{60}$

Offentleglova $\$ 24$ annet ledd gir derfor generell hjemmel til å unnta dokument om lovbrudd fra innsyn inntil saken er avgjort. Dette gjelder både dokumenter organet mottar fra andre, men også alle dokumenter som omhandler og er forfattet som følge av lovbruddet, for eksempel der forvaltningen ber om opplysninger eller redegjørelser fra andre. ${ }^{61}$ Forhåndsvarsel til parten kan således unntas fra offentlighet i overtredelsessaker. Det er ikke nødvendig at det faktisk er skjedd et lovbrudd. Forvaltningens behandling vil jo ofte skje bl.a. for å avklare nettopp det.

Unntaksadgangen er knyttet til «dokument om lovbrot». Det er ikke noe vilkår at det er snakk om et straffbart lovbrudd. Bestemmelsen omfatter også lovbrudd som er underlagt administrative sanksjoner som for eksempel overtredelsgebyr, tilbakekall av tillatelser o.lign. Den omfatter imidlertid ikke sak om hvorvidt det skal rettes kritikk mot noen for brudd på god forvaltningsskikk el.lign.

Selv om dokumenter i overtredelsessaker kan unntas fra offentlighet, er det ikke dermed sagt at forvaltningen ikke kan gi tilgang til dem eller offentlig omtale de forhold dokumentene omhandler. Også i slike saker gjelder meroffentlighetsregelen i $\$ 11$ om at organet bør gi innsyn dersom hensynet til offentlig innsyn veier tyngre enn behovet for unntak. De hensyn som ligger til grunn for unntaksadgangen tilsier imidlertid også at forvaltningen utviser forsiktighet i sin omtale i de tilfeller der innsyn gis.

Taushetsplikten som er behandlet ovenfor i tilknytning til omtale av vedtak gjelder selvsagt også i sakens tidligere faser. Før vedtak er truffet er det neppe grunn til å gjøre unntak fra taushetsplikten ut fra hensynet til individual- eller almenprevensjon. Hensynet til å advare publikum kan imidlertid i enkelte tilfelle komme inn.

Hvis det gis innsyn eller forvaltningen omtaler saken i media før behandlingen er ferdig, tilsier det forhold at det at saken ikke er avgjort tilbakeholdenhet for ikke å foregripe det endelige vedtak. I en sak som gjaldt forvaltningens anmeldelse av et forhold til politiet uttalte ombudsmannen:

${ }^{60}$ NOU 2003:30 Ny offentlighetslov s. 205

61 Se Ot.prp.nr.102 (2004-2005) Om lov om rett til innsyn i dokument i offentleg verksemd (offentleglova) s. 146.
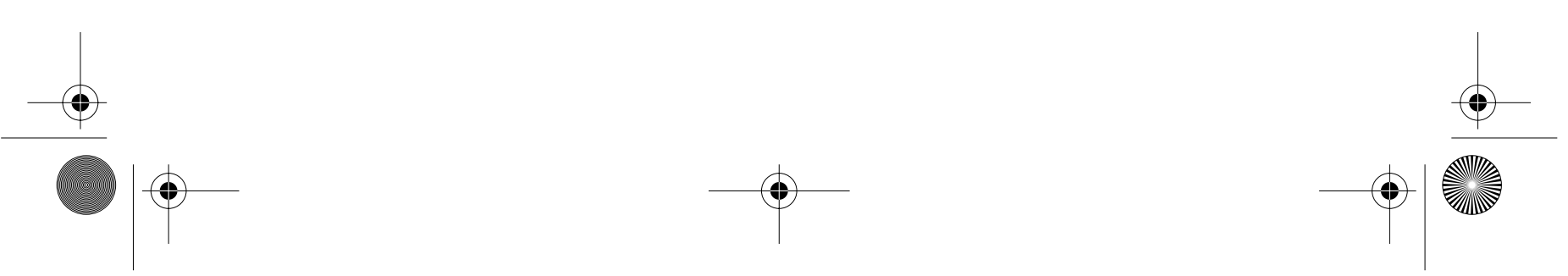
«Når en offentlig tjenestemann uttaler seg om en anmeldt, siktet eller tiltalt person eller et anmeldt og påstått straffbart forhold, er det viktig å passe på at prinsipper og hensyn som vår rettergangsordning bygger på, blir tilfredsstillende ivaretatt. Når forvaltningen har anmeldt noen for et straffbart forhold, bør den innta en objektiv og upartisk stilling. De som uttaler seg på det offentliges vegne, bør da også søke å gi sine uttalelser form og innhold som gjenspeiler den objektive og upartiske holdningen offentlige myndigheter skal innta i forbindelse med straffeforfølgning.» og videre at anmeldte må kunne «vente at offentlige myndigheter og tjenestemenn opptrer på samme måte i forhold til dem som til borgerne for øvrig, på en saklig og hensynsfull måte og for øvrig tar slike hensyn som prinsippene i EMK artikkel 6 nr. 2 bygger på. Forbudet mot å omtale en person på en måte som vil kunne oppfattes som en konstatering av at vedkommende er skyldig før straffesaken er endelig avgjort av domstolene, legger føringer på hvordan en offentlig tjenestemann på embets vegne bør uttale seg til offentligheten.» ${ }^{62}$

I den aktuelle saken kritiserte ombudsmannen at den som uttalte seg på vegne av forvaltningen karakteriserte parten som «svært arrogant» og uttalte at parten «med viten og vilje har overtrådt norsk lov og da må hun som norsk borger ta ansvaret for det».

De betraktninger ombudsmannen bygget på i tilknytning til forvaltningens anmeldelse må ha betydning også for de krav som stilles til forvaltningens uttalelser der det er organet selv som skal treffe det endelige vedtaket. Parten har ofte ikke har hatt anledning til å komme med sitt syn på saken og imøtegå eller kommentere de faktiske forhold før forvaltningen kommer med sitt forhåndsvarsel. Det forhold at de opplysninger forvaltningen bygger på i varselet ikke har vært undergitt en kontradiktorisk behandling tilsier forsiktighet med å gi offentligheten innsyn i dem. Når det er forvaltningsorganet selv som skal treffe avgjørelse kommer også habilitetshensyn inn - uttalelsene må ikke gi inntrykk av at hva parten skulle komme med av kommentarer til varselet ikke vil spille noen rolle for vedtakets utfall. Uavhengig av om forhåndsomtalen fører til inhabilitet vil offentlighet og en eventuell medieomtale av saken kunne undergrave tilliten til at det skjer en reell og kontradiktorisk behandling av saken hvor partenes anførsler tas hensyn til før en-

62 Sivilombudsmannens årsmelding 2002 s. 79.
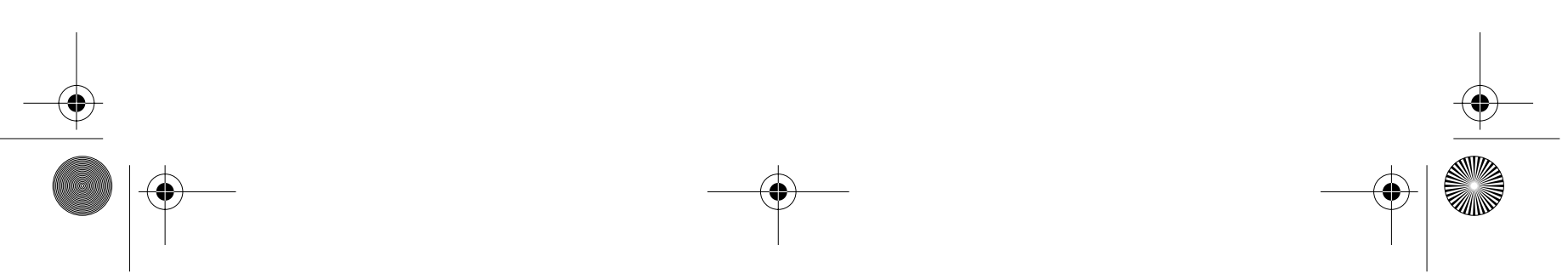
delig vedtak treffes. ${ }^{63}$ Departementet uttaler i stortingsmeldingen om ytringsfrihet at

«Om den ansatte selv skal håndtere saken, eller vedkommendes plassering i hierarkiet gjør det naturlig for allmennheten å anta at vedkommende vil ha intern innflytelse, må den ansatte unngå å skape inntrykk av at vedkommende har bestemt seg på forhånd - før saken er ferdig utredet. Dette er nødvendig for å ivareta allmennhetens og eventuelle parters tillit til beslutningsprosessen. Gir en tjenestemann uttrykk for et klart standpunkt utad mens saksbehandlingen pågår, kan det også forstyrre saksbehandlingen innad.» ${ }^{64}$

Mitt inntrykk er at enkelte tilsynsorganer ofte går ganske langt i sine uttalelser i saker som er under behandling, i alle fall i forhold til de krav som ombudsmannen har stilt med utgangspunkt i prinsippene om god forvaltningsskikk.

Se til illustrasjon utdrag fra pressemelding fra Konkurransetilsynet publisert dato: 19.09.2005: "Varsler overtredelsesgebyr til TINE for brudd på konkurranseloven. Konkurransetilsynet vurderer å ilegge TINE BA et overtredelsesgebyr på inntil 45 millioner kroner for brudd på konkurranseloven. Tilsynet mener TINE har misbrukt sin dominerende stilling ved å inngå en avtale med Rema 1000 AS om at TINE skulle være eneleverandør av ost. TINE forsøkte også å inngå en tilsvarende avtale med ICA Norge AS. I et varsel om vedtak 19. september fikk TINE beskjed om Konkurransetilsynets foreløpige konklusjon i saken.Konkurransetilsynets etterforskning har vist at TINE og Rema 1000 tidlig høsten 2004 ble enige om at TINE skulle være eneleverandør av ost til Rema. TINE og Rema inngikk eneleverandøravtalen før Rema og Synnøve Finden startet sine forhandlinger for 2005. Først i desember 2004 ble Synnøve Finden kjent med at selskapet ikke ville få fornyet sin avtale med Rema for 2005.»

Som en kontrast se pressemelding fra Konkurransetilsynet publisert dato: 31.03.2006: «Kystbuss-samarbeid kan være ulovlig. Konkurransetilsynet vurderer å pålegge HSD Buss AS, Connex Vest AS og Gaia Reiser AS å avvikle sitt samarbeid om Kystbussen. De tre selskapene driver

63 Se NOU 2003:15 Fra bot til bedring s. 207.

${ }^{64}$ St.meld. nr. 26 (2003-2004) Om endring av Grunnloven $\$ 100$ s. 104.
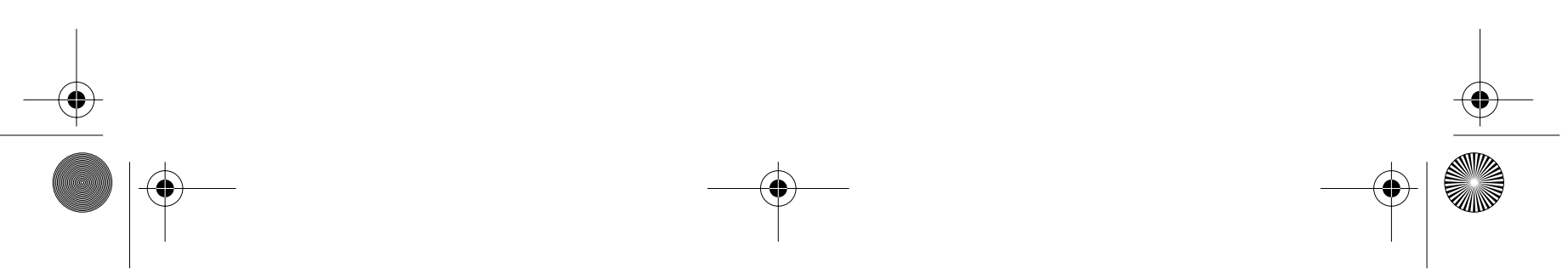
Kystbussen, som er en ekspressbusstjeneste på strekningen mellom Bergen og Stavanger.

Konkurranseloven forbyr samarbeid som begrenser konkurransen. Konkurransetilsynet mener at samarbeidet mellom HSD Buss, Connex Vest og Gaia Reiser om Kystbussen kan være forbudt. Derfor vurderer tilsynet å pålegge selskapene å avvikle samarbeidet. I tillegg til kan det bli aktuelt med overtredelsesgebyrer på til sammen inntil 3,5 millioner kroner.

Undersøkelser tyder på at det bare er Flaggruten (båt) og Kystexpressen (buss) som konkurrerer med Kystbussen på strekningen, ${ }_{\curlywedge}$

Også ombudsmannen har gitt uttrykk for bekymring i forhold til utviklingen i forvaltningens medieopptreden i overtredelsessaker. I en sak om Kreditttilsynets medieopptreden i forbindelse med politianmeldelser fra 1988 uttalte ombudmannen:

«Det synes for øvrig å være en tiltagende tendens til å offentliggjøre opplysninger i forbindelse med politianmeldelser, og mitt inntrykk er at det ofte skjer primært for å skape publisitet omkring organets arbeid, og vel også for å oppnå en «skremselseffekt». Dette er ikke uten betenkeligheter, blant annet fordi det er uvisst om saken ender opp med en fellende straffedom. Behovet for en gjennomtenkning av problemstillingene og for en klar regelfesting melder seg altså også på andre felter enn på verdipapirhandelens område.» ${ }^{65}$

Noen generell lovregulering av disse forholdene foreligger ennå ikke. Særlige rettslige begrensninger utover dem som følger av taushetsplikten er det derfor vanskelig å oppstille. Når slike begrensninger skal vurderes kan man ikke bare ta hensyn til parten. Man må også ta hensyn til ytringsfriheten. Denne avveiningen omtales straks nedenfor.

\subsection{Omtale uten tilknytning til et aktuelt vedtak}

Som nevnt i avsnitt 3.2 ovenfor, er aktiv informasjon, også om enkeltpersoner og -bedrifters forhold, en viktig del av oppgaven til en del offentlige tilsyn. Det betyr at det kan være aktuelt for et organ å gå offentlig ut med informasjon om konkrete forhold også uavhengig av at det foreberedes eller er truffet et vedtak. Hvor det ikke er satt i gang noen sak om enkeltvedtak, gjelder i utgangspunktet ikke forvaltningslovens

\footnotetext{
65 Sivilombudsmannens årsmelding 1988 s. 76
}
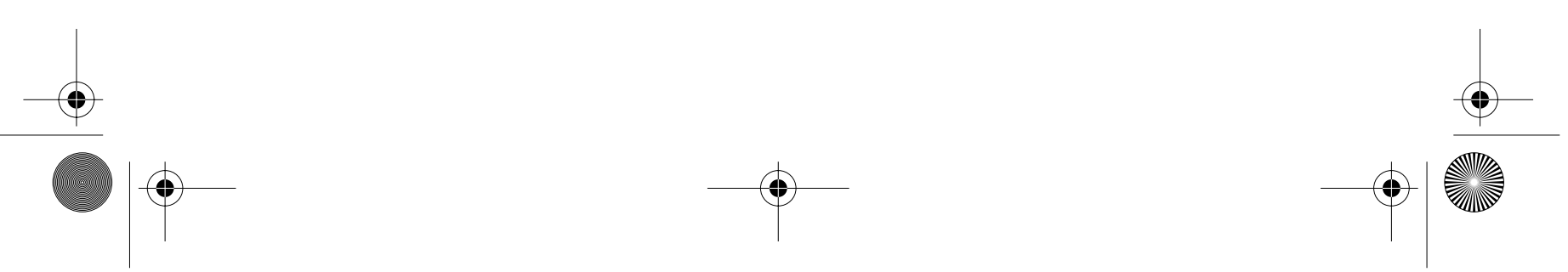
regler om partsinnsyn og forhåndsvarsel. Det finnes ingen særlig lovregulering av de krav som må stilles til forvaltningens saksbehandling og vurderinger før det gis informasjon til offentligheten som kan være belastende for fysiske eller juridiske personer.

Selv om et forhold faller utenfor forvaltningsloven kapittel IV-VI om saksforberedelse ved enkeltvedtak, er det ikke dermed sagt at det ikke gjelder krav til behandlingen. Dersom det er tale om å foreta handlinger som kan få stor eller inngripende betydning for private, kan krav for å vareta hensynet til kontradiksjon oppstilles enten på grunnlag av ulovfestede prinsipper eller pr. analogi fra forvaltningsloven. ${ }^{66}$

På den annen side gjelder ytringsfriheten også for forvaltningen. Forvaltningens og offentlige tjenestemenns ytringsfrihet må sees i lys av de oppgaver som hører under vedkommende myndighet og at offentlige myndigheter har en aktiv plikt til å bidra til å gi informasjon på sitt forvaltningsområde. Den tjenestemann som uttaler seg offentlig på embets vegne, må som utgangspunkt ha rett til fritt å velge ord, uttrykk og karakteristikker som finnes passende for den situasjonen og de formålene uttalelsen er ment for. ${ }^{67}$ Generelt å si at en offentlig tjenestemann ikke skulle kunne uttale seg om forhold eller personer uten å gjøre uttalelsene gjenstand for en kontradiktorisk behandling, ville nærme seg å innføre forhåndssensur for forvaltningens ytringer. Etter mitt syn skal det derfor mye til før man kan begynne å snakke om partsrettigheter o.lign. i forhold til forvaltningens ytringer eller medieopptreden.

Med referanse spesielt til et tilsynsorgans offentlig kunngjøring knyttet til forhold rundt en konkret bedrift har ombudsmannen uttalt:

«Selv om kunngjøringen ikke er ment som en sanksjon overfor selskapet, vil den rent faktisk kunne få alvorlige økonomiske konsekvenser. Det må derfor stilles strenge krav til saksbehandlingen. Kredittilsynet må gå varsomt frem og offentliggjøringen må bygge på et saklig og forsvarlig grunnlag. Dette innebærer bl.a. også at Kredittilsynet ikke skal gå lenger enn det som forholdene gjør det påkrevet, bl.a. for å hindre at godtroende klienter lider tap.» ${ }^{68}$

${ }^{66}$ Se nærmere Hans Petter Graver, Alminnelig forvaltningsrett, 2. utg., Oslo s. $381 \mathrm{flg}$.

67 Se Sivilombudsmannens årsmelding 2002 s. 79.

68 Sivilombudsmannens årsmelding $1991 \mathrm{s.} 98$
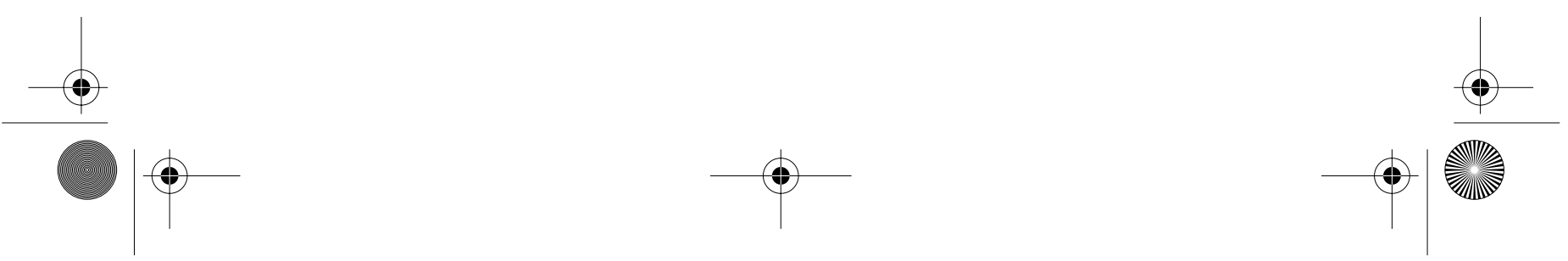
Det ombudsmannen oppstiller her er et slags krav til overveielse og forholdsmessighet. På den annen side kan man neppe gå særlig langt i denne retning de lege lata. I Rt. 1962 s. 193 godtok Høyesterett nokså knusende omtale fra Forbrukerrådets side om et produkt uten at det ble snakk om å pålegge staten erstatningsansvar, selv om retten oppfattet pressemeldingen som "uheldig og delvis støtende» i sin utforming. Dommen er ganske gammel, men oppfattes fortsatt som uttrykk for gjeldende rett. ${ }^{69}$

Ganske langt i retning av å oppstille kontradiktoriske rettigheter går forarbeidene til matloven. Her sier departementet:

«Før tilsynsmyndigheten informerer offentligheten, skal om mulig den berørte part informeres om hva tilsynsmyndigheten vil informere om og på hvilken måte. Virksomheten bør få en kort tidsfrist til å kunne oppklare eventuelle faktiske feil eller misforståelser. Tilsynets rett til å offentliggjøre opplysninger reduseres ikke av uenighet fra virksomhetens side, men det er viktig at tilsynet er klar over hvilken makt det ligger i denne typen offentliggjøring slik at den diskresjonære adgangen benyttes skjønnsomt. Tilsynet bør foreta en vurdering av hva den oppnår med å informere sett hen til eventuelle skadevirkninger for virksomheten. Gjennom media kan denne typen informasjon gi til dels store skadevirkninger for den som omtales.» ${ }^{70}$

Uttalelsene om saksbehandlingen kan muligens ses i lys av at tilsynet har hjemmel til også å røpe taushetsbelagte forhold i sin informasjon til offentligheten. Noe grunnlag for å anse de krav til saksbehandlingen som oppstilles som uttrykk for generelle krav forvaltningen bør følge, finnes etter mitt syn ikke. Ombudsmannen har ansett at grunnlaget for å oppstille de krav han har stilt ikke er «noenlunde konkrete og etablerte saksbehandlingsregler", men "god forvaltningsskikk» som rettesnor for fremtidig praksis. ${ }^{71}$ På dette området har således ombudsmannen mer sett det som sin oppgave å veilede forvaltningen enn å refse.

\footnotetext{
69 Se Viggo Hagstrøm, Det offentliges ansvar for feilaktig informasjon i Festskrift til Carl August Fleischer, dog Fred er ej det Bedste, Oslo 2006 s. 217-224.

70 Ot.prp.nr.100 (2002-2003) Om lov om matproduksjon og mattrygghet mv. (matloven) s. 163.

71 Sivilombudsmannens årsmelding 1991 s. 98.
}
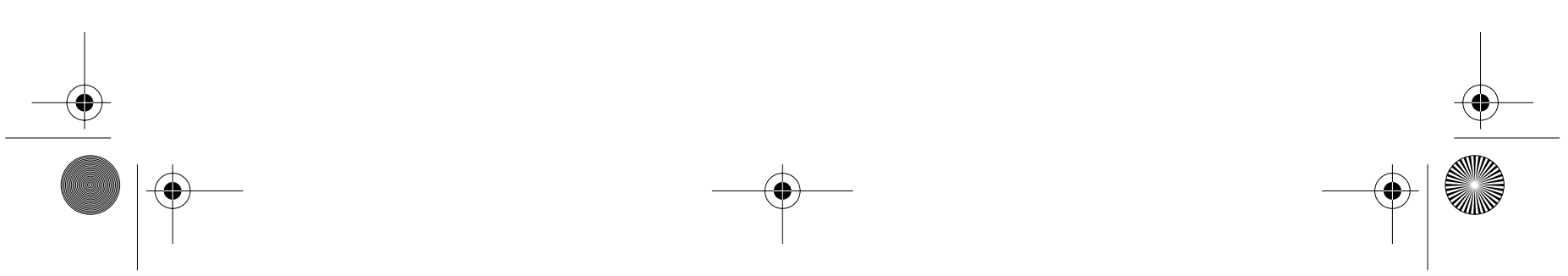


\subsection{Reaksjoner}

\subsubsection{Brudd på taushetsplikt}

Brudd på taushetsplikt er straffbart. Prinsipielt sett kan det derfor reageres med straff mot en tjenestemann som røper taushetsbelagte opplysninger i offentligheten selv om dette skjer i embets medfør på vegne av virksomheten. I praksis skal det nok mye til før det kan bli aktuelt å straffe slike forhold i tilknytning til omtale av en sak forvaltningen behandler, med mindre det er klare forretningshemmeligheter eller sensitive personopplysninger som røpes. I alle fall er det vanskelig å tenke seg en slik reaksjon der forvaltningen har trådt feil i sin vurdering av der rettslige grunnlaget for å beskytte en part mot at det blir offentlig at forvaltningen vurderer eller har truffet vedtak om å sanksjonere brudd på offentligrettslige plikter. Grensene er her usikre, og forvaltningen vil ofte ha grunn til å uttale seg i de regler og de hensyn som ligger til grunn for organets virksomhet. En trussel om straff kan bent frem virke uheldig i forhold til at organet nettopp skal vareta offentlige interesser også gjennom opplysning til publikum om ulovlige og klanderverdige forhold. På dette grunnlag er det å håpe at lovgiveren følger opp forslaget fra sanksjonsutvalget om at opplysning om vedtak om administrativ sanksjon, eller om lovovertredelse som et slikt vedtak er eller kan bli basert på skal unntas fra taushetsplikten.

\subsubsection{Inhabilitet som folge av uttalelser}

Uttalelser som skjer som ledd i forberedelsen av en sak kan skade tilliten til at forvaltningen vil forta den fortsatte behandlingen på en uhildet måte. I yttertilfellene kan uttalelsene ha et slikt innhold eller form, at den som kommer med dem må anses inhabil i den fortsatte saksbehandlingen. Er det organets leder som har uttalt seg, vil konsekvensen være at ingen av de ansatte i organet kan treffe vedtaket, jf. forvaltningsloven $₫ 6$ fjerde ledd. Ombudsmannen har på generelt grunnlag uttalt at

«det kan være grunn til å påpeke at tjenestemenn og folkevalgte som skal være med på å treffe enkeltvedtak i mange tilfeller bør være seg bevisst sin rolle dersom det er tale om å engasjere seg i offentlig debatt. Ønsker man å delta i denne, hvilket man selvsagt både kan og bør, må man imidlertid være forberedt på at engasjementet da kan være egnet til
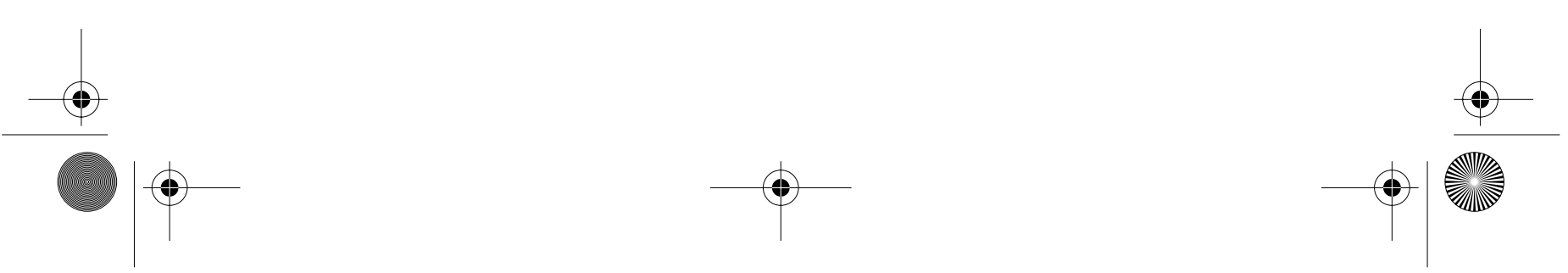
å svekke tilliten til en senere deltakelse i saksbehandling og avgjørelse av enkeltsaken.» $^{72}$

Det skal likevel mye til før en uttalelse om en sak til behandling kan medføre at den som uttaler seg blir inhabil til å fortsette saksbehandlingen eller treffe vedtak i saken. Det finnes lite veiledning for vurderingen i praksis eller teori. Når det gjelder dommeres habilitet etter den strengere regelen i domstolloven $₫ 8$ er oppfatningen at det skal mye til for et generelt engasjement og deltakelse i debatten om tilsvarende spørsmål som dem som står til pådømmelse kan føre til inhabilitet. Har dommeren uttalt seg offentlig om saken, eller spørsmål i nær tilknytning til denne, kan det lettere tenkes at han er inhabil, se Rt. 1993 s. 1094. På den annen side vil det forhold at dommeren under saksforberedelsen eller hovedforhandlingen i en sak gir uttrykk for hvordan saken bør behandles, eller kommer med saklige innvendinger mot de resonnementer som blir fremført, normalt ikke føre til inhabilitet. ${ }^{73}$

Dommere forventes å ha en mer tilbaketrukket rolle i offentligheten enn forvaltningen. Forvaltningen har som nevnt en plikt til å gi informasjon, også om saker til behandling. At en embets- eller tjenestemann gir uttrykk for genelle standpunkter i offentligheten kan vanskelig føre til inhabilitet, selv i saker hvor forvaltningen må ta stilling til disse spørsmålene, sml. for dommere Rt. 1983 s. 490 og 2000 s. 38. Offentlige uttalelser om saken som står til behandling kan heller ikke føre til inhabilitet så lenge de innskrenker seg til å gi informasjon om saken og forvaltningens behandling av dem. Dette må være tilfellet selv om uttalelsene gis en spissformulert form, og går noe lengre $\mathrm{i}$ å forklare eller begrunne de skritt forvaltningen har tatt enn det som fremgår av sakens dokumenter. Det er bare om uttalelsene gir uttrykk for et særlig engasjement i forhold til den aktuelle saken som ikke står i forhold til dens viktighet for organet, eller hvor vedkommende i form eller innhold opptrer over grensen til det kritikkverdige at det kan bli tale om inhabilitet.

Til illustrasjon kan nevnes kjennelsen til kjæremålsutvalget i Rt. 2005 s. 172. En dommer hadde gitt en advokat det glatte lag både i domsgrunner og i pressen. Kjæremålsutvalget kom til at han var inhabil i saker der advokaten opptrådte, men uttalte også: «Motsetninger mel-

72 Sivilombudsmannens årsmelding 2000 s. 23-24.

73 Se Jens Edvin A. Skoghøy, Tvistemål, 2. utg., Oslo 2001 s. 112
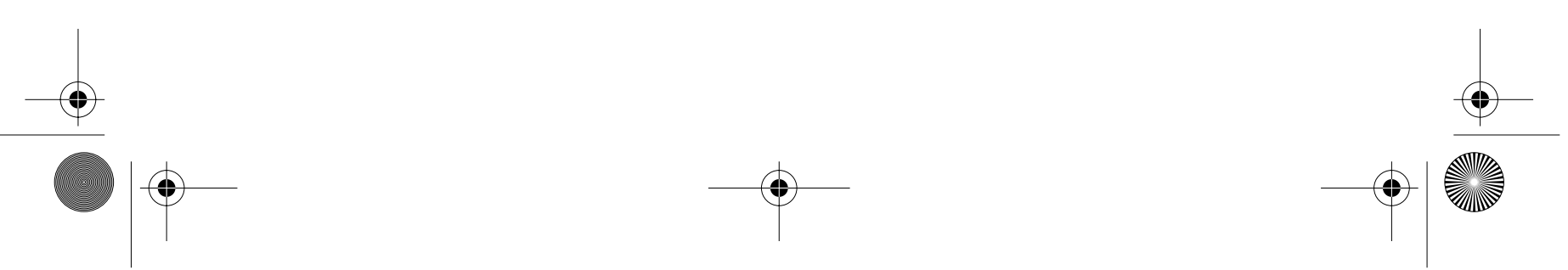
lom advokater og dommere er ikke sjeldent forekommende i rettslivet. Det sier seg selv at det ikke medfører inhabilitet at dommeren mister prosessfullmektigens tillit på grunn av innholdet i avgjørelser som treffes, eller på grunn av negative uttalelser om advokatens sakførsel, hva enten uttalelsene fremkommer i avgjørelsen eller under saksforberedelsen eller hovedforhandlingen i saken. Advokaten må også tåle at kritikken er skarp. Som lagmannsretten understreker, skal dommeren opptre saklig og holde en nøktern tone. Det er likevel ikke slik at det uten videre medfører inhabilitet at dommeren opptrer kritikkverdig i forhold til en advokat. Dette vil etter omstendighetene kunne gi grunnlag for klage til Tilsynsutvalget for dommere, jf. domstolloven $\$ 235$ flg., men er normalt uten betydning for dommerens habilitet. Skal dommeren vike sete, må det således dreie seg om kritikkverdige forhold av en særlig karakter, som er egnet til å så tvil om dommerens uhildethet i en sak der advokaten, som det er et motsetningsforhold til, opptrer. At dommeren har opptrådt uakseptabelt i flere saker med ulike advokater, og derved mer generelt kan kritiseres, eksempelvis for sin prosessledelse, vil ikke gjøre ham inhabil i enkeltsaker.»

\subsubsection{Erstatning}

Det kan også unntaksvis tenkes at forvaltningen kan bli erstatningsansvarlig for økonomisk tap som følge av uttalelser om en person eller et foretak. Også i forhold til disse reglene må det trekkes vide rammer ut fra hensynet til at forvaltningen skal oppfylle de regler og mål som ligger til grunn for dens virksomhet.

Hvor det gis informasjon om vedtak som er truffet er det vanskelig å tenke seg et erstatningsansvar for det offentlige med mindre taushetsplikten er overtrådt. Dette må gjelde selv om vedtaket senere skulle bli omgjort eller opphevet. I slike tilfelle må et ansvar grunnes på reglene om statens erstatningsansvar for ulovlige myndighetshandlinger. Offentlighet om vedtaket og eventuelle konsekvenser av denne vil kunne komme inn som moment i erstatningsutmålingen.

Når det gjelder informasjon som gis om behandlingen av en sak, må utgangspunktet også her være at det offentlige ikke kan bli erstatningsansvarlig for denne. Det er klarligvis ikke rom for noe ansvar som følge av at en sak blir offentlig ved at pressen bruker offentlighetslovens reg-
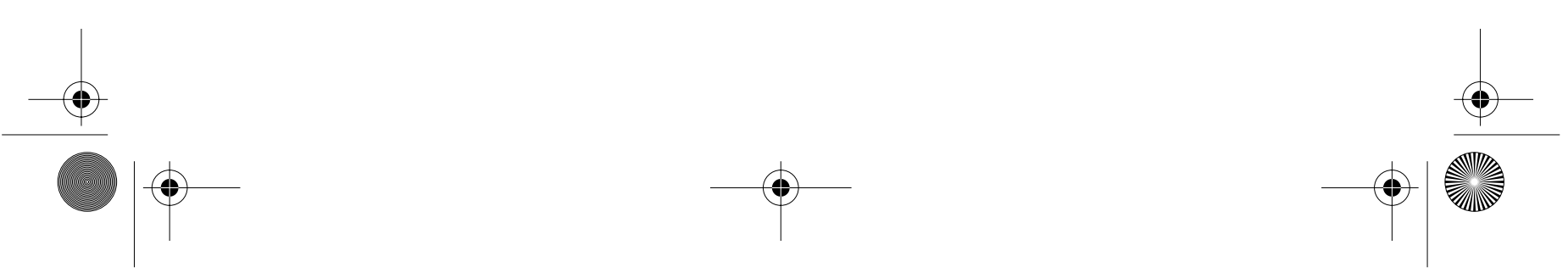
ler. Det samme må gjelde selv om forvaltningen praktiserer meroffentlighet. Med forbehold for offentleglova $\$ 24$ om saker om lovbrudd, er ikke unntaksreglene gitt av hensyn til den som er omtalt i et dokument hos forvaltningen. Det spiller ingen rolle i vurderingen at opplysningene som gjøres kjent senere viser seg å være uriktige. Det er nettopp forvaltningens rolle i mange tilfelle å undersøke hva som medfører riktighet i konkrete tilfeller. Når forvaltningens dokumenter er offentlige, innebærer det at lovgiver har tatt generelt standpunkt til avveiningen mellom på den ene side offentlighetens krav på innsyn og på den annen side parters og andres ønske om diskresjon om at forvaltningen behandler en sak som gjelder dem.

Heller ikke der forvaltningen ut fra sine generelle oppgaver går ut med informasjon til almenheten uten at det skjer i tilknytning til en aktuell sak er det særlig rom for ansvar, selv der informasjonen viser seg å være uriktig. ${ }^{74}$ Generelt er jeg enig med det Hagstrøm uttaler med hensvisning til Bertil Bengtson, at ansvar bare utgår der det ville være nærmest støtende om det offentlige gikk fri.

\section{Bruk av offentligheten for å pàvirke offentlige instanser}

Offentlige organer og ledere bruker også media for å påvirke utfallet av beslutninger som treffes av andre offentlige organer og politiske myndigheter. I noen tilfeller er dette en klar del av et organs oppgaver og mandat, som for eksempel barneombudet som «har til oppgave å fremme barns interesser overfor det offentlige og private», se barneombudloven $₫ 3$. Ovenfor er også nevnt konkurranseloven $₫ 9$ e om at konkurransetilsynet skal påpeke konkurranseregulerende virkninger av offentlige tiltak. Mange offentlige organer går ut aktivt for å påvirke også uten et slikt uttrykkelig mandat. I forbindelse med høringen av forslag til nye reformer blir alltid organer med oppgaver på vedkommende område spurt. I denne forbindelse ligger det i systemet at organet skal fremme sitt syn og dermed forsøke å øve innflytelse på den beslutningsprosessen som følger etter høringsrunden. Det samme er tilfelle i behandlingen av klage i enkeltsaker, hvor jo det organ som har

\footnotetext{
${ }^{74}$ Se Viggo Hagstrøm, Det offentliges ansvar for feilaktig informasjon i Festskrift til Carl August Fleischer, dog Fred er ej det Bedste, Oslo 2006 s. 217-224.
}
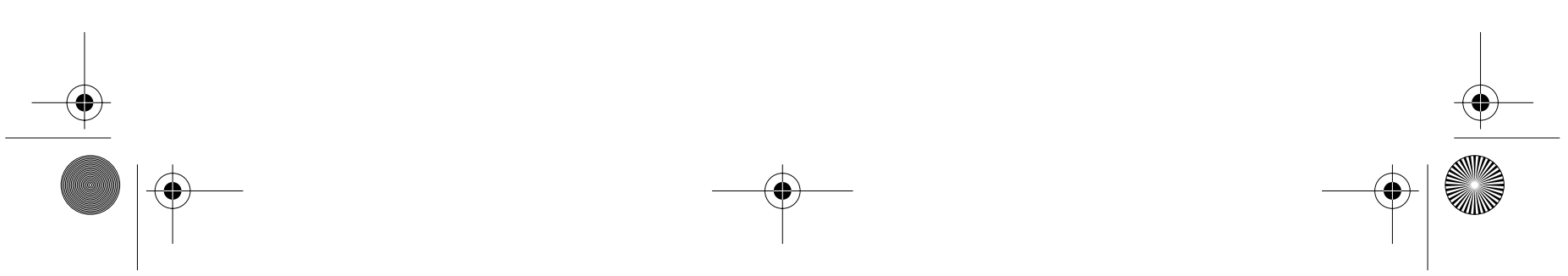
truffet vedtaket skal gjennomgå klagen og i uttrykk for sitt syn på den overfor klageinstansen.

Det varierer hvor sterkt offentlige organer markedsfører sin uttalelse eller søker å øve innflytelse på beslutninger hos overordnede eller i politiske organer utenfor høringsbehandlingen eller forberedelsen av en klagesak. I noen tilfeller kan et underordnet organ søke å påvirke opinion og politikere i forbindelse med en klagesak for å gjøre det vanskelig for det overordnede organet å omgjøre i klageomgang. I andre tilfelle kan det være ressurser eller fullmakter organet er ute etter å oppnå. I atter andre kan medieopptreden være ledd i faglig opplysning av så vel politikere som almenheten for øvrig. Mens de fleste vil være enig om at det siste er både legitimt og ønskelig innen visse grenser, kan det være større uenighet om den første typen aktivitet som går på å «redde» organets eget vedtak. Dette illustrerer at det kan være vanskelig å ha generelle standpunkter eller gi klare regler for hvordan forvaltningsorganer og de som uttaler seg på disses vegne kan opptre som opinionspåvirkere i media når det ikke er direkte rettet til adressater for reglene under organets ansvarsområde.

I amerikansk teori og debatt om offentlige reguleringer snakker man om behovet for «advocacy» fra tilsynsorganers side for å utgjøre en motvekt i den politiske prosessen mot sterke og organiserte krefter i bl.a. markedet.

"It is useful to identify a public entity tasked with the responsibility of representing dispersed consumers and competition as an end in itself in the political process. Concentrated interests can always hire lobbyists and experts to explain why their industry is "different» and thus should be exempt from the discipline of the market process. A competition authority, expert in understanding the competitive process, can explain to the public and to generalist political actors whether these calls for industry-specific regulation will really further the public good. Advocacy also can inform consumers of their interests in a regulation, perhaps spurring the desire to organize politically to oppose a regulation that will result in higher prices and less choice.» ${ }^{75}$

Det synes å være bred enighet om at det må trekkes et skille mellom ansatte i departementene på den ene siden, og direktorater og ytre etat på den annen side. Som ytringsfrihetskommisjonen sier det:

75 Cooper, James C., Pautler, Paul A. and Zywicki, Todd J., «Theory and Practice of Competition Advocacy at the FTC». Antitrust Law Journal, Vol. 72, No. 3, pp. 1091 1112,2005 
Idealet om et nøytralt embetsverk tilsier at de ledende embetsmenn $\mathrm{i}$ departementene ikke offentlig gir til kjenne en egen agenda og standpunkter på tvers av regjeringen. Prisen man betaler for nærhet til makten er følgelig redusert ekstern ytringsfrihet - en pris de ansatte i departementenes ledelse synes å ha vært villig til å betale. ${ }^{76}$

Det er en klar forskjell mellom ledende embetsmenn i departementene og ledere for etater og underordnede organer at de siste ikke kan skille i offentligheten mellom egne og organets standpunkter. Begge hører til den personkrets som har en slik posisjon i systemet at forvekslingsfare ikke kan unngås, slik at de i realiteten ikke har noen «egen» ytringsfrihet i behold. ${ }^{77}$ Mens en ekspedisjonssjef ikke har lov til å gi uttrykk for egne meninger offentlig, har en etatssjef ikke mulighet til det fordi hans eller hennes uttalelser vanskelig kan skilles fra etatens. Det har selvsagt sammenheng med at ekspedisjonssjefen er underlagt statsråden, mens etatssjefen selv er øverste leder for organet. En annen sak er at organet, og dermed etatssjefen etter omstendighetene har plikt til underordne seg, og dermed ikke offentlig motarbeide statsrådens og departementets beslutninger og oppfatninger.

Departementene kan ikke offentlig ha andre standspunkter enn dem som inntas av statsråden eller regjeringen. Når det gjelder den øvrige forvaltningen må utgangspunktet være at lojaliteten mot regjeringen og departementet må veies opp mot offentlige ansattes plikt til lojalitet til det demokratiske system i seg selv, herunder hensynet til en best mulig informert offentlig debatt. Offentlig ansatte som sitter med rent faglige oppgaver, enten de har faglig ansvar for utdanning, helse, kommunikasjon eller forsvar, for nevne noe - besitter en faktisk kompetanse som ikke bør stenges ute fra det offentlige rom. De bør derfor ha både rett og plikt til å redegjøre for problemer, utfordringer og mulige løsninger på sitt fagfelt. ${ }^{78}$ Departementet uttaler i Stortingsmeldingen om ytringsfrihet at "offentlig ansatte, utenom ansatte som arbeider for et sekretariat underlagt politiske organer, bør ha stor ytringsfrihet når ytringen gir kunnskap til allmennheten om et spørsmål som det er naturlig at allmennheten tar stilling til, og denne kunnskapen ikke fremkommer

\footnotetext{
76 NOU 1999:27 «Ytringsfrihed bør finde Sted» s. 131.

77 Se nærmere Sivilombudsmannens årsmelding 2002 s. 66 og St.meld. nr. 26 (20032004) Om endring av Grunnloven $₫ 100$ s. 104.

78 Se NOU 1999:27 «Ytringsfrihed bør finde Sted» s. 129.
}
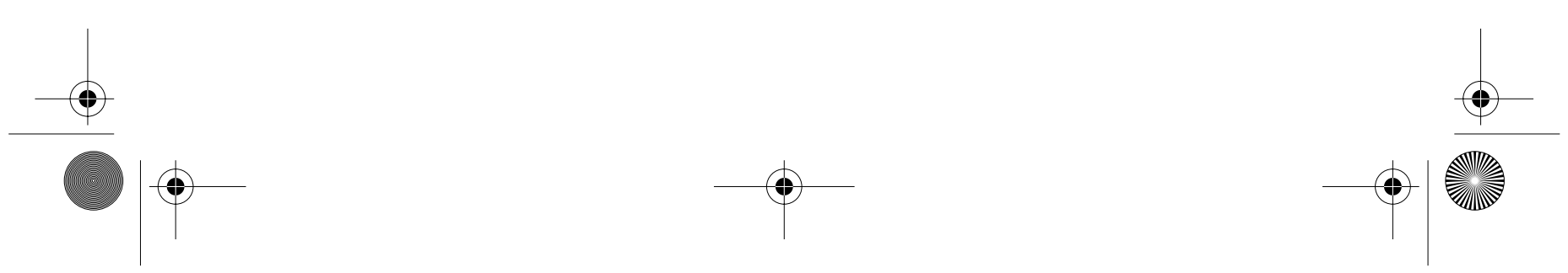
på annen måte.» ${ }^{79}$ Utgangspunktet er at det forventes faglig uavhengighet av den enkelte tjenestemann og dermed underliggende organer. ${ }^{80}$

På den annen side ligger det klare begrensninger når de uttaler seg på vegne av organet eller i kraft av sin stilling. Offentlig ansatte plikter som andre ansatte å ta hensyn til hva arbeidsgiveren, og dermed regjeringen og departementet er tjent med. Dette gjelder enn mer når de opptrer i tjenesten. En etatsleder må derfor ikke uttale seg eller opptre på en slik måte at han skader virksomheten eller de interesser den ivaretar.

I en eldre sak for ombudsmannen hadde en fylkesveterinær tatt kontakt med stortingskomiteen for å få støtte til tiltak mot sauesykdommen mædi etter at han forgjeves hadde prøvd seg i departementet. ${ }^{81}$ Departementet rettet sterk kritikk mot ham for å ha undergravet tilliten til departementets tiltak for bekjempelse av sykdommen. Departementet mente at hans henvendelse til Stortinget var et brudd på den lojalitetsplikt overfor regjeringen/Landbruksdepartementet som han som embetsmann hadde plikt til. Ombudsmannen mente at det ikke var gitt at samme regler om adgang til å ta initiativ til møte eller drøftelse med komiteer i Stortinget skal gjelde for embets- og tjenestemenn i den ytre etat som i departementet. Han la vekt på at de tiltak veterinæren søkte å fremme gjaldt et supplement til eller en videreføring av de tiltak som departementet hadde fastsatt for bekjempelse av mædi; det var ikke tale om endring, omgåelse eller kritikk av departementets tiltak. Selv om ombudsmannen kunne forstå dem som mente at fylkesveterinæren ikke burde tatt kontakt med stortingskomiteen, forsto han ikke den sterke kritikken som departementet hadde rettet mot ham.

I kommentarene til punkt 2.1 lydighetsplikten i etiske retningslinjer for statstjenesten sier Moderniseringsdepartementet at statsansatte ikke skal ha kontakt med Stortingets komiteer eller komitéfraksjoner uten at dette er klarert med overordnet departement. I forhold til det ombudsmannen uttrykte er dette for kategorisk. Selv om retningslinjene er nyere enn ombudsmannsaken, er rettskildeverdien av en slik kommentar til noen retningslinjer ganske lav.

Ytringsfriheten og hensynet til at almenheten får tilgang til faglige

79 St.meld. nr. 26 (2003-2004) Om endring av Grunnloven $₫ 100$ s. 110.

80 Jf. St.meld. nr. 11 (2000-2001) Om forholdet mellom embetsverket, departementenes politiske ledelse og andre samfunnsaktører (avsn 24).

81 Sak $1209 / 75$.
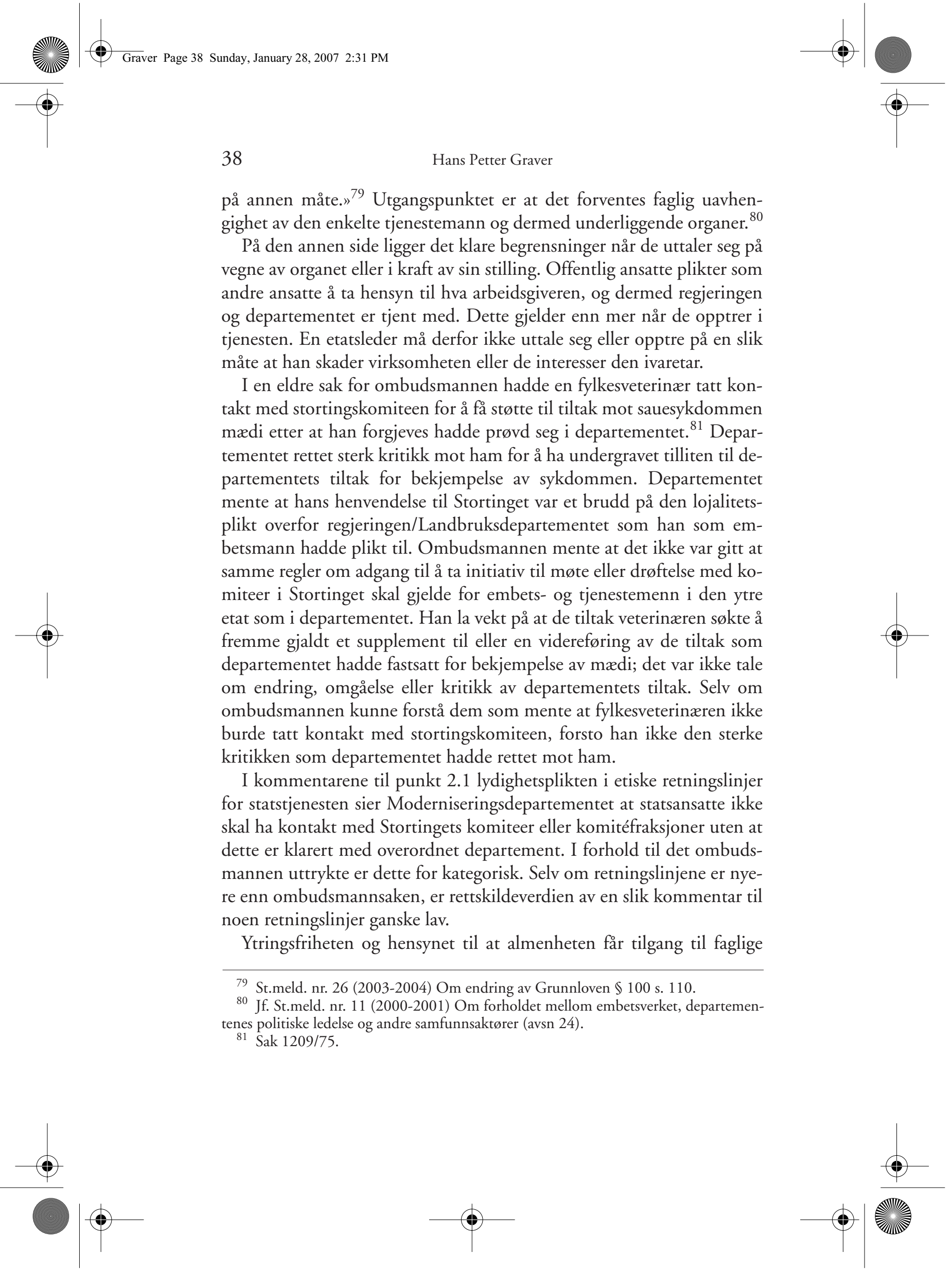
vurderinger og synspunkter hos ansvarlige fagetater er sterke hensyn som taler for at etatsledere og andre på etaters vegne kan delta i den alminnelige debatt om spørsmål innen etatens område. De bør ikke være bundet i så måte til å fremme regjeringens eller departementets syn. På den annen side tilsier mangelen på innsyn og demokratisk innflytelse innad i etatene tilbakeholdenhet. Det er ikke særlig demokratisk at offentlige ledere skal kunne bruke organets ressurser og posisjon i samfunnet til å fremme rent personlige holdninger og oppfatninger. Underordnede ansatte har frihet til å ytre seg på egne vegne. Denne friheten har ikke ledere av offentlige virksomheter innen sitt eget fagområde.

Tar vi utgangspunkt i disse vurderinger må vi kunne si at et organ og dets ledelse må avstå fra offentlig å kritisere lovlige beslutninger regjeringen eller departementet har truffet. Slike beslutninger må selvsagt lojalt etterleves, og det vil også være organets plikt til å informere og søke å skape forståelse for slike beslutninger innen sitt område. Det må på den annen side være tillatt for organet å peke på konsekvenser av beslutningen der disse er annerledes enn det som var fremme i beslutningsprosessen. Hvor langt organet kan gå i denne retning i offentligheten må avgjøres ut fra et skjønn over hvorvidt grensen mot uakseptabel omkamp er overtrådt.

På den annen side må en offentlig leder kunne bruke offentligheten til å argumentere for sitt syn der regjeringen eller departementet ennå ikke har truffet noen beslutning. Talsmenn for organet må likevel selvsagt avholde seg fra partipolitisk virksomhet og ytringer som kan reise tvil om deres evne til å oppfylle sine embetsplikter på en upartisk måte. Argumentasjonen må dessuten ikke skje på en slik måte at den skader omdømmet eller tilliten til organet selv eller dets overordnede instanser. De overordnede organer må også innenfor de vanlige rammer for styring ha anledning til å bestemme hvor denne grensen går og instruere underordnede etater om dette.

\section{Konklusjoner}

Gjennomgangen har vist at rettsreglene om forvaltningens mediehåndtering er få og rammen for forvaltningens opptreden vid. Dette preger også de reaksjoner som står til rådighet for den som føler seg krenket eller skadet ved forvaltningens medieopptreden. De fleste av de krav som
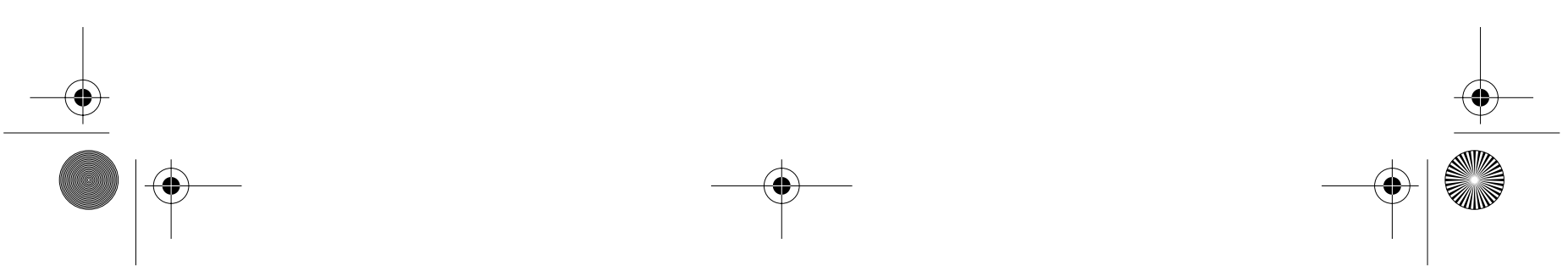
kan stilles til forvaltningens saksbehandling og vurdering før den ytrer seg har karakter av krav til god forvaltningsskikk og ikke av rettsregler. Det betyr at parter ikke kan påberope seg rettigheter overfor forvaltningen på grunnlag av dem, for eksempel krav om å får seg forelagt en uttalelse for å oppklare misforståelser før den offentliggjøres. I den utstrekning det kan oppstilles rettskrav for å sikre kontradiksjon før forvaltningen uttaler seg, vil brudd på disse likevel vanskelig kunne ha noen direkte konsekvenser. I motsetning til et vedtak kan ikke en ytring kjennes ugyldig. Selv om en saksbehandlingsregel skulle være brutt, bør det neppe gi grunnlag for å kreve for eksempel at forvaltningen skal trekke tilbake eller beriktige sin uttalelse. Uttalelsen kan jo være adekvat og treffende selv om parten ikke har fătt uttale seg.

Her som ellers bør den primære reaksjonen på en uriktig eller ubehagelig omtale være å gripe til den offentlige meningsveksling. Vanlige krav til pressetikk tilsier at den som er omtalt av forvaltningen i et massemedium gis anledning til å imøtegå det som er sagt, enten i samme eller i et senere oppslag. Så lenge vi har en fri presse, er dette en ganske god garanti mot at forvaltningens versjon får dominere offentligheten. På den annen side kan man ikke helt se bort fra at det vi snakker om er bruk av virkemidler av representanter for øvrigheten. Å gi staten og statens ledere ytringsfrihet er ikke reglenes primære formål. Det vil være en pervertering å anvende grunnleggende rettigheter på en slik måte at de åpner for overgrep fra statens side overfor private.
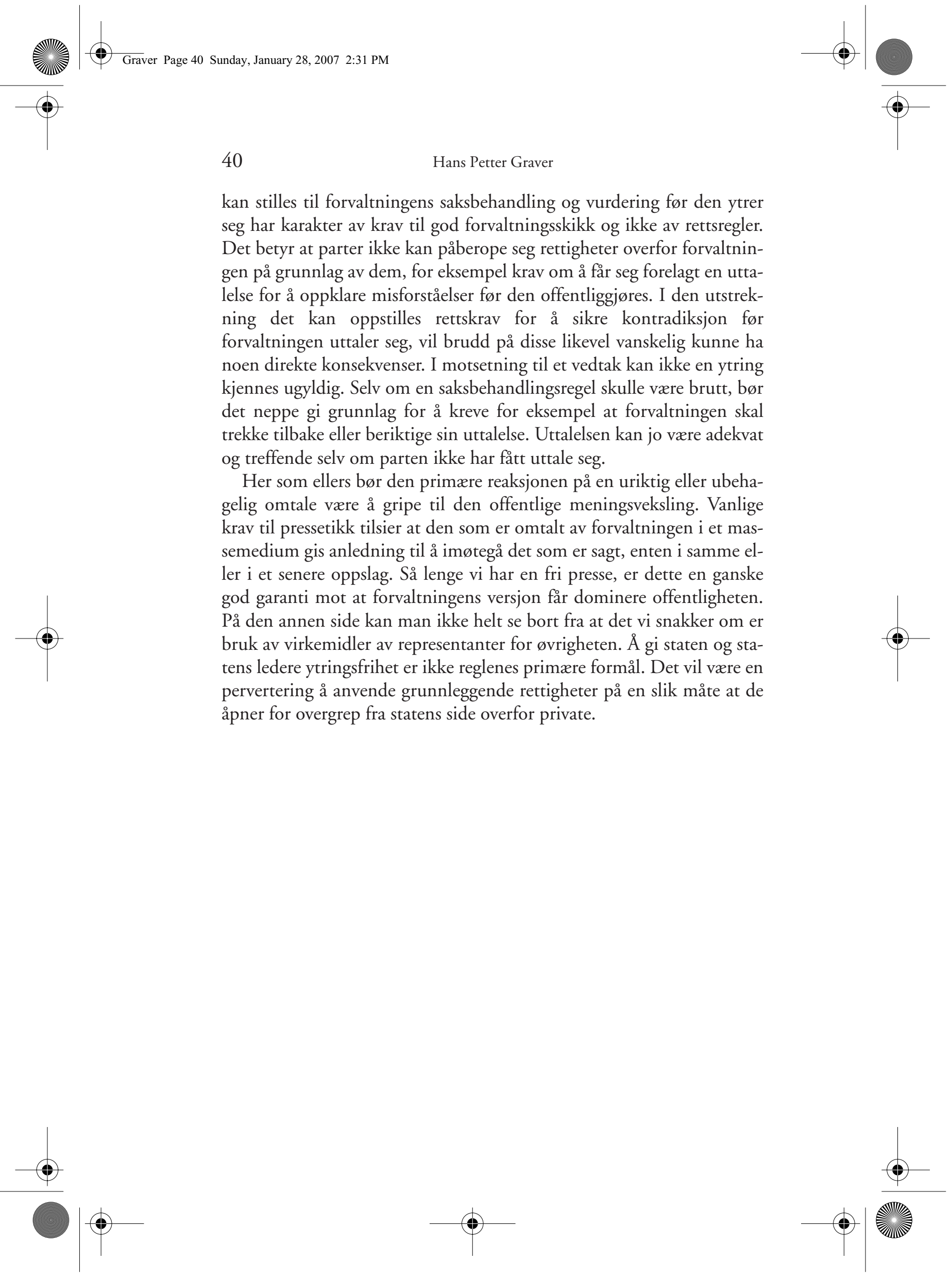